NBER WORKING PAPER SERIES

\title{
THE RECENT TRANSFORMATION OF PARTICIPATORY EMPLOYMENT PRACTICES IN JAPAN
}

\author{
Takao Kato \\ Working Paper 7965 \\ http://www.nber.org/papers/w7965 \\ NATIONAL BUREAU OF ECONOMIC RESEARCH \\ 1050 Massachusetts Avenue \\ Cambridge, MA 02138 \\ October 2000
}

\begin{abstract}
I owe my greatest debt of gratitude to NBER, NIRA, JCER, JIL, Rengo-Soken, JPC-SED, Richard Freeman, Motohiro Morishima, Professors Koike and Fujimura of Hosei University, Mr. Nakashima and Mr. Koike of Rengo-Soken, Mr. Fukutani of JPC-SED, and the managers, foremen and union officials of Japanese companies who granted me the opportunities to interview them. An earlier version of the paper was presented at the joint JCER-NBER Conference on Labor Markets and Firm Benefit Policies in Japan and the United States, January 20-23, 2000, Hawaii. I benefited greatly from comments made by Richard Freeman, Professor Chuma of Hitotsubashi University, and other conference participants. The views expressed in this paper are those of the author and not necessarily those of the National Bureau of Economic Research.
\end{abstract}

(C) 2000 by Takao Kato. All rights reserved. Short sections of text, not to exceed two paragraphs, may be quoted without explicit permission provided that full credit, including (C) notice, is given to the source. 
The Recent Transformation of Participatory Employment Practices in Japan

Takao Kato

NBER Working Paper No. 7965

October 2000

JEL No. J53, J33, J24, J41, L2, M11, M12, O53

\begin{abstract}
Using both quantitative data from national surveys and qualitative data from our own field research, this paper provides evidence on changes in participatory employment practices in Japan during the economic slowdown in the 1990s. Overall, consistent with the complementarity of such practices and the long-term nature of their effects, evidence points to the enduring nature of such practices (except for small to medium size firms with no union where we find evidence for management to try to weaken the role of employee participation).

There are, however, a few early signs of trouble even for large, unionized firms, which might eventually result in the breakdown of the system if left untreated. First, while the number of full time union officials has been falling substantially as a result of continued downsizing of the firm's labor force, the amount of time and effort that union officials need to put into participatory employment practices have not been falling. This often results in an uncompensated increase in workload for union officials. If this trend continues, union officials who have been playing a key role in Japanese participatory management will become less effective and less committed to the interest of the rank and files. Second, top management sometimes finds its participatory management system detrimental to timely and efficient management, and hence tries to streamline the system. Overloaded union officials may offer less resistance to this kind of management initiative. Third, the current system tends to produce a gap in the quantity and quality of information acquired from management between top union officials and their general membership. It is conceivable that such a gap may eventually result in the breakdown of the system.
\end{abstract}

\title{
Takao Kato
}

Department of Economics

Colgate University

Hamilton, NY 13346

Ph: 315-228-7562

Fax: 315-228-7033

tkato@mail.colgate.edu 


\section{THE RECENT TRANSFORMATION OF PARTICIPATORY EMPLOYMENT PRACTICES IN JAPAN}

\section{$\underline{\text { I. Introduction }}$}

In many countries around the world, management systems are changing away from the traditional system characterized by often adversarial collective bargaining and a fixed wage contractual payment basis. Prominent among these changes is the explosion in the use and interest in participatory employment practices. ${ }^{1}$ This paper presents findings from our most recent research on the transformation of participatory employment practices of Japanese firms in the 1990s during which the Japanese economy slowed down considerably.

A closer look at the Japanese experience of employee participation and labor-management cooperation appears to be of particular public policy interest for many countries considering participatory employment practices a way to improve their productivity performance and thus competitiveness.

First, as Levine and Tyson (1990) suggest, relatively higher job security (often ensured by intrafirm transfers and transfers to related firms) and strong group cohesiveness (supported by compression of wage and status differentials) of Japanese workers in large manufacturing firms in the postwar period point to an industrial relations system favorable to successful employee participation. Moreover, relatively more rapid and stable growth in the postwar period, lower unemployment and stable financial corporate grouping (banks and institutional shareholders as stable, long-term suppliers of capital) point to an external environment favorable to successful employee participation.

Probably as a result of these favorable environments in the postwar Japanese economy, in particular in manufacturing, participatory employment practices spread widely and were established firmly. $^{2}$ Indeed these practices became the hallmark of "Japanese management," which has been inspiring (or necessitating in some instances) many corporations in the world to experiment with employee involvement and labor-management cooperation in recent years (see, for instance, Levine, 1995: 5). In

\footnotetext{
${ }^{1}$ See, for instance, Commission on the Future of Worker-Management Relations (1994) and Levine (1995).

${ }^{2}$ See, for instance, Kato and Morishima (1999).
} 
short, the postwar Japanese economy (especially in manufacturing) clearly represents one of the most important examples of experimentation with participatory employment practices.

The economic slowdown in the 1990s (in particular the recent banking crisis) and a rapidly aging workforce have allegedly been eroding the aforementioned participation-friendly environments. Have participatory employment practices that we find successful for the 1960s, 1970s and 1980s been surviving in Japan in the 1990s? If so, how have they been evolving to cope with these new environments in the 1990s? Are there any differences between sectors in the survival of participatory employment practices? A closer look at the recent Japanese experience with participatory employment practices will help us understand better two key questions regarding participation: (i) what are the conditions under which participatory employment practices are best introduced and best sustained; and (ii) in what way participatory employment practices will need to evolve when external environments change. To address these questions, we have been gathering and analyzing both quantitative data from national surveys and qualitative data from our own field research on evolving employment practices in the 1990s. This paper reports the first findings from our analysis of these data on the responses of Japanese firms in their use of participatory employment practices to the economic slowdown in the 1990s.

The paper is organized as follows. In the next section, we provide an overview of the scope, nature and effects of participatory employment practices in postwar Japan. Sections III and IV present our findings on the responses of Japanese firms in their use of participatory employment practices to the economic slowdown in the 1990 s, followed by a concluding section.

\section{The Scope, Nature and Effects of Participatory Employment Practices in Japan}

We first provide an overview of participatory employment practices in Japan, followed by a brief review of the evidence on their effects on firm performance.

Joint Labor Management Committees (JLMCs): Information sharing at the top.

One of the core mechanisms for labor-management relations within a large Japanese firm is joint 
labor-management committees (JLMCs). Established at the top level (corporate and/or establishment level) and involving both management and union representatives, JLMCs serve as a mechanism for information sharing at the top level on a large variety of issues ranging from basic business policies to working conditions.

When there is a union, labor-side representatives are almost always union representatives, while even in the absence of unions, the majority of labor-side JLMC members are elected by employee vote (about 70\%, Koike, 1978). Thus, labor-side JLMC members usually legitimately represent the interests of the firm's workforce.

According to Shimada (1992), JLMCs were one of the many labor-management institutions proposed at the beginning of 1950s by the Japan Productivity Center. After a decade of tumultuous labor-management relations between 1945 and 1955, Japanese unions and management, with the endorsement from the central government, began to implement a number of well-known human resource management techniques including JLMCs and semi-annual bonus payments to all employees. According to Kato and Morishima (1999), in 1950 about 20 percent of all publicly traded firms including both manufacturing and non-manufacturing firms had standing JLMCs. During the next two decades, the institution diffused rapidly (at a rate of about 20 percentage points for each decade). Thus, by 1970 the figure had risen to close to 60 percent. For the next two decades the institution diffused steadily, and, as of 1993, fully 80 percent of all publicly traded firms reported to have standing JLMCs.

Many observers attribute the peaceful firm-level labor relations observed in Japanese firms to the establishment of JLMCs (Shimada, .1992; Inagami, 1988). Within JLMCs, which meet almost once a month, a number of issues are discussed, ranging from basic business policies to social and athletic activities sponsored by the firm (see Kato and Morishima, 1999). The nature and scope of information shared during the JLMC meetings will be discussed in detail in Sections III and IV.

\section{$\underline{\text { Shop-floor Committees (SFCs): Information sharing at the grass roots }}$}

Aside from JLMCs and formal trade unions, many Japanese corporations have shop-floor committees 
(SFCs) in which supervisors and employees on shop floor discuss issues such as shop-floor operations and shop-floor environments. Though the potentially important role of SFCs in the Japanese industrial relations system has been suggested (see, for instance, Koike, 1978), the nature and scope of these SFCs have not been studied extensively largely due to the absence of reliable data. A recent survey conducted by Kato and Morishima (1999) reveals that the average SFC meets about nine times a year (slightly less frequently than JLMCs); and that information shared during the SFC meetings tends to go beyond standard shop-floor issues such as safety and health, fringe benefits, training and development, and grievances, and includes business and strategic plans. As such, SFCs are aimed at information sharing at the grass roots level.

Kato and Morishima (1999) also reveals the diffusion of SFCs among Japanese firms in the postwar era. In 1950, only 7 percent of all publicly traded firms including both manufacturing and nonmanufacturing firms had a standing SFC. During the next decade the institution did not diffuse much, reaching only 11 percent of publicly traded firms by the end of the decade. Since then, however, the institution diffused steadily; in 1993 more than 40 percent of all publicly traded firms reported to have standing SFCs (for manufacturing firms, more than 50\% reported to have standing SFCs).

\section{$\underline{\text { Small Group Activities (SGAs) }}$}

SGAs are activities such as quality control (QC) circles and Zero Defects in which small groups at the workplace level voluntarily set plans and goals concerning operations and work together toward accomplishing these plans and goals. The wide use of SGAs such as QC circles by Japanese firms is, by now, quite well-known (see, for instance, Cole, 1989). In 1950 almost no publicly traded firm (only 3 percent) used an SGA. In 1960 only 6 percent of all publicly traded firms had an SGA. The rapid diffusion of the institution began in 1960s. By the beginning of 1970s, about one in four publicly traded firms were practicing an SGA, and the figure reached 44 percent in 1980. Since then the institution has grown steadily; in 199370 percent of all publicly traded firms reported practicing an SGA (Kato, 1995). 
employees practice an SGA as opposed to 43 percent of firms with 299 or fewer). Moreover, SGAs are more wide-spread in the unionized sector (Kato, 1995).

\section{Employee Stock Ownership Plans (ESOPs): Financial Participation via Stock}

Japanese ESOPs are perhaps best understood by comparing their main features with the better known U.S. ESOPs. Unlike U.S. ESOPs, Japanese corporations establishing an ESOP (called mochikabukai) do not receive any tax incentive to do so. To induce individual employees to participate in the ESOP, companies offer subsidies (typically the firm matching each employee's contribution by giving 5 to 10 percent of the contribution as well as bearing administrative costs). Whereas ESOPs elsewhere frequently are structured so as to encourage strong participation by top management, in Japan executives (as well as part time and temporary employees) are normally ineligible for membership. As is the norm elsewhere, individual participants' shares (and dividends) in the ESOP are held in trust. Unusually, however, each participant has a right to withdraw his/her shares, and share withdrawals are privately owned. Withdrawals are permitted only in 1,000 shares, round lots. While members may freely exit completely from the ESOP, re-entry is restricted. Exiting employees will receive their shares in 1,000 shares, round lots, and must sell the remaining shares to the trust at the prevailing market price. Upon retirement, model rules adopted by most ESOPs require retiring workers to exit completely from the ESOP. Finally, the general director (rijicho) represents stockholders in the ESOP. The general director is chosen by other participants, on a one-participant, one-vote basis. At the general meeting of shareholders, the general director votes the stock held by the plan, deciding independently, rather than by tabulating votes of employee participants. The general director must be a participant in the ESOP and thus is not an executive (Jones and Kato, 1995).

The survey conducted by Kato and Morishima (1999) shows that ESOPs are a relatively new and the most rapidly diffused innovation among various Japanese participatory employment practices. Thus, in 1960 the proportion of publicly traded firms that had an ESOP was only 4 percent. The proportion grew rapidly during the next decade, reaching 26 percent by 1970. In 1967, a special government committee on foreign capital advocated employee ownership as a way to help prevent foreign takeovers of domestic 
firms. The government, using informal channels, encouraged firms to set up new ESOP trusts to accommodate employee investments in their stock. While the fear of foreign takeovers diminished in the 1970s, the idea of employee ownership took root. Perhaps partly due to this government initiative of 1967 , the 1970s were characterized by an astonishing pace of diffusion of the institution, and over two thirds of publicly traded firms came to have ESOPs by the end of the 1970s. The diffusion continued even after 1980, and in 1993 it became almost a universal phenomenon among publicly traded firms.

The survey also shows that in 1993, almost 50 percent of the labor force in firms with ESOPs participated in ESOPs. Furthermore, concerning employee stakes, Jones and Kato (1995) report that, in 1988, ESOPs owned stock worth 4.1 trillion yen (about 32 billion dollars); this amounts to 1.7 million yen (about 14,000 dollars) per participant.

However, according to Jones and Kato (1995), these plans do not own large percentages of company stock. For listed companies the average proportion of stock owned by ESOPs has varied between 0.66 percent and 1.42 percent from 1973 to 1988 . In 1988 the average was lower than 1 percent and holdings over 5 percent were rare.

\section{Profit Sharing Plans (PSPs): Financial Participation via Bonus}

PSPs are a pay system in which the total amount of bonuses are linked to a measure of firm performance, such as profit. The Japanese bonus payment system has attracted considerable attention and controversy (e.g. Freeman and Weitzman, 1987, Nakamura and Nakamura, 1989, Hashimoto, 1990, Hart and Kawasaki, 1995). In light of the ongoing debate between those who stress the profit sharing aspect of the Japanese bonus system (e.g., Freeman and Weitzman, 1987) and those who downplay it (e.g., Ohashi, 1989, Brunello, 1991), we consider only the least controversial (with respect to the profit-sharing aspect of the bonus payment system) types of the bonus payment system, i.e., the bonus payment system with a formal contract stipulating the presence of the profit-sharing plan.

According to Kato and Morishima (1999), one in four publicly traded firms had a PSP in 1993 (no appreciable difference between manufacturing and non-manufacturing firms). The proportion of publicly 
traded firms with a PSP was only 5 percent in 1960 and grew steadily to 14 percent by 1980 . A significant diffusion occurred during the 1980s, however, with the proportion of publicly traded firms with PSPs growing to over 20 percent by 1990 .

PSPs are found to be more prevalent in smaller firms. For instance, the proportion of firms with 5,000 or more employees that had a PSP was only 11 percent. The large majority (70 percent) of firms with a PSP reported separate profit-sharing plans for officers and non-officers. However, Japanese PSPs do not normally distinguish between union and non-union members (only one-thirds of firms with PSPs reported separate PSPs for union and non-union members). PSPs are mostly company-wide with only 12 percent of firms with PSPs reporting separate plans for different divisions and occupations. Moreover, nearly all Japanese PSPs are cash plans (98 percent), which is in sharp contrast to the U.S. where deferred plans are more popular (see Kruse 1993: 16-17). Being almost always cash plans, Japanese PSPs have no tax advantage.

The majority of Japanese PSPs (55 percent) do not have set formula (or are fully discretionary) for how the contribution should be tied to profits, which is also in contrast to PSPs in the U.S. where only 22 percent are fully discretionary (Kruse, 1993: 75).

\section{Evidence on their effects}

In spite of the importance of the postwar Japanese experience with participatory employment practices, there is not much systematic investigation of the economic effects of participatory employment practices in Japan. ${ }^{3}$ For the economic effects of financial participation, the Japanese bonus payment system has

\footnotetext{
${ }^{3}$ For U.S. corporations, however, we are presently witnessing an impressive growth of evidence. See, for example, Ichniowski, Shaw and Prennushi (1997), Freeman, Kleiner, and Ostroff (1997), Black and Lynch (1997), Freeman and Kleiner (1998), Susan Helper (1998), Bartel (2000) and articles featured in a special issue of Industrial Relations (Vol. 35, July 1996). Many of these recent studies in the U.S. use plant-level (branch-level) panel data within a narrowly defined industry. The benefits of using such data are probably less dramatic for Japan than for the U.S. since Japanese firms are generally substantially smaller (see, for instance, Kato and Rockel, 1992's comparative study of the 1,000 most valuable corporations between the two nations), and their management appears to be less decentralized than U.S. firms. Based on our interviews with managers in human resource at the corporate level and top managers in marketing/sales and accounting/finance at the business unit level of Japanese and U.S. corporations, the power of human resource department at the corporate level relative to top management at the business unit level appears to be much stronger in Japan than in the U.S. In addition, as Jones and Kato (1995) and Kato and
} 
attracted considerable attention and controversy, in particular the claim that it is a form of a PSP. Earlier studies focused on the effects on employment of the Japanese bonus payment system. ${ }^{4}$ More recent studies turned to the issue of the productivity effects of the Japanese bonus payment system. Jones and Kato (1995) use firm-level panel data to find that there is a modest productivity gain from the bonus system. Ohkusa and Ohtake (1997) find that firms with a statistically significant positive correlation between their wages and per capita profit are 9 percent more productive than firms without such a correlation. For ESOPs, Jones and Kato (1995) use firm-level panel data to find that the introduction of an ESOP will lead to a 4 to 5 percent increase in productivity and that this productivity payoff does not appear immediately.

For the economic effects of information sharing at the top level, Morishima (1991a; 1991b) use firm-level micro data to find the statistically significant positive correlations between the extent of information sharing through JLMCs and productivity, and the statistically significant correlations between stronger JLMCs and shorter and smoother wage negotiation. More recently, Tsuru and Morishima (1999) use two unique data sets, one from a survey of firms and the other from a survey of employees, and find evidence for positive correlations between the presence of JLMCs and the strength of "employee voice."

Finally, Kato and Morishima (1999) find evidence for the importance of introducing groups of participatory employment practices in the following three areas: (i) information sharing at the top level; (ii) information sharing at the grass roots level; and (iii) financial participation. Specifically, moving from the traditional system of no participatory employment practice to a highly participatory system with participatory employment practices in all three areas lead to a significant 8- to 9-percent increase in productivity. The full productivity effect is, however, felt only after a fairly long developmental phase (7 years). At the same time, they find no evidence for significant productivity gains from changing the industrial relations system from the traditional system to any intermediate systems which lack participatory employment practice in at least one of the three key areas.

Morishima (1999) show, there are substantial lags (up to 7 years) in the productivity effects of participatory employment practices in Japan. Plant-level data seldom provide long longitudinal data and thus may not be as useful in the context of the postwar Japanese experience as in the context of the current U.S. experimentation.

${ }^{4}$ See, for example, Freeman and Weitzman, 1987 and Brunello (1991) 
In sum, there is evidence for the positive effects of participatory employment practices in Japan in the postwar period, supporting that such practices help align the interest of the firm with the interest of its employees and encourage specific human capital accumulation of employees. ${ }^{5}$ In addition, recent findings from Kato and Morishima (1999) suggest that the goal alignment process needs to be supported both by direct methods (financial participation) and indirect ones (information sharing). Furthermore, information sharing needs to take place not only at the top level but at the grass roots level. In other words, the goal alignment process occurs most strongly when the interests of the two parties are aligned through financial participation and when this interest alignment is facilitated by mechanisms both at the top level and at the grass roots level which curtail parties' opportunistic behavior.

Kato and Morishima (1999)'s findings also point to the importance of a long-term perspective in evaluating the success of participatory employment practices. First, it does take time for the goal alignment process to take root. It is highly unlikely that instituting a participatory employment practice will instantly create significant interest alignment of groups of employees with the firm. ${ }^{6}$ Furthermore, there is substantial learning by doing in the evolution of participatory employment practices. Participatory employment practices "mature" over time and only matured participatory employment practices tend to yield significant productivity gains.

\section{Evolving Practices in the 1990s: Quantitative Evidence}

In this section, we report the first findings from our analysis of the quantitative data from national surveys on evolving participatory employment practices in the 1990s.

\section{A. ESOPs in the 1990s}

The National Conference Board of Securities Exchanges has been conducting annually the Survey of Stock

\footnotetext{
${ }^{5}$ See Kato and Morishima (1999) for further discussion on the goal alignment and human capital effects of these practices as well as their complementarity effects.

${ }^{6}$ For similar arguments, see Pil and MacDuffie (1996) and Ichniowski and Shaw (1995).
} 
Distribution to which all firms listed on Japan's stock exchange markets respond. The National Conference Board has recently released summary tables from their 1997 Survey. Using these most recently published summary tables as well as earlier tables, we created Figures 1, 2, and $3 .^{7}$

In the 1980 s, the share prices of most large corporations in Japan rose steadily. It is not too surprising under such steady growth of corporate profitability that ESOPs gained increasing popularity in Japan. Thus, as shown in Figure 1, both the proportion of firms with ESOPs and the ESOP participation rate (the proportion of the labor force in firms with ESOPs who participate in ESOPs) grew steadily in the 1980s. Moreover, the real market value of outstanding shares owned by ESOPs more than quadrupled and the real market value of outstanding shares owned by ESOPs per participant (the real value of the average stake) more than doubled in the 1980s. The National Conference Board also published the average price of shares owned by ESOPs (the market value of outstanding shares owned by ESOPs divided by the total number of shares owned by ESOPs). The real value of this average price tripled in the 1980 s.

The steady growth of share prices ended rather abruptly at the end of the 1980s. For instance, the average firm listed in the Tokyo Stock Exchange lost more than half its value in the early 1990s (Kang and Stulz, 1998). Reflecting this rapid asset price deflation in the early 1990s, the real market value of outstanding shares owned by ESOPs, the real value of the average stake, and the real value of the average price of shares owned by ESOPs fell sharply in the early 1990s. As shown in Figure 1, recovery from this sharp drop has been anemic.

A most natural question concerning the responses of ESOPs to this seemingly powerful adverse shock is whether this adverse shock has been discouraging employees from participating in ESOPs. Figure 1 shows a surprisingly calm response of the labor force in firms with ESOPs. The ESOP participation rate has not fallen in any significant way in the 1990s although its steady increase in the 1980s did stop in the 1990s: the ESOP participation rate rose in the 1980s by 9 percentage points from 40 to 49 percent and has remained at 49 percent level in the 1990s. It is, however, unclear whether the stagnation of the

\footnotetext{
${ }^{7}$ Although the Survey began in 1973, data on market value of outstanding shares owned by ESOPs became
} 
participation rate in the 1990s is caused by the adverse financial shocks. At any rate, there has not been any sign of a frenzied exit of participants from ESOPs in response to the adverse financial shock in the 1990s.

Consistent with this relatively calm response of employees, very few employers have terminated their ESOPs in response to the adverse financial shock. Thus, as shown in Figure 1, the proportion of firms with ESOPs has not fallen in the 1990s and ESOPs have continued to be a near universal phenomenon among publicly traded firms in Japan (95 percent of all publicly traded firms have ESOPs).

Overall, it appears that neither employees nor employers have panicked in the face of the adverse financial shock in the 1990s. In addition to the summary table for all publicly traded firms, the National Conference Board publishes the summary table for two-digit industries. Conceivably the adverse shock might have been hitting certain industries particularly hard and for those hard-hit industries, many ESOPs might have been terminated and the ESOP participation rate might have been falling significantly. To see if this is the case, we produced Figures 2 and 3. As shown in both figures, we failed to find any noteworthy example of such industries although as shown in Figure 3, the ESOP participation rate has fallen to some extent from 1988 to 1997 for mining, textiles, steel, primary metals, transportation equipment, wholesale and retail trade, finance and insurance, real estate, and service. Somewhat surprisingly, however, the ESOP participation rate has risen substantially over the same time period for a few industries, in particular oil and coal, land transportation, water transportation and transportation by air.

\section{B. JLMCs in the $1990 \mathrm{~s}$}

The Survey of Labor-Management Communications conducted in 1995 by the Ministry of Labour provide the most recent aggregate data on JLMCs. The same survey was conducted also in 1988 by the Ministry. ${ }^{8}$

available only in 1979. Thus, our complete data on the evolution of ESOPs begin in 1979.

${ }^{8}$ Among all establishments in Japan that employ 50 or more employees, the Ministry of Labour selects 4000 of them and sends its researchers to each establishment. These experienced Ministry researchers then fill out the questionnaire by asking each establishment questions from the questionnaire. 
Using various cross tabulations published from the 1995 survey as well as those from the 1988 survey, we produced Figures 4-11.

First, Figure 4 shows how the proportion of establishments with JLMCs has changed from 1988 to 1995. For all establishments (labeled "total" in the figure), like in the case of ESOPs, the proportion of establishments with JLMCs has not fallen significantly over this time period, remaining a little below 60 percent. ${ }^{9}$ In other words, overall, the economic slowdown in the 1990s in general and the recent banking crisis in particular have not caused any significant dismantling of JLMCs. ${ }^{10}$

Again, conceivably the adverse shock might have been hitting certain sectors of the economy particularly hard and for those hard-hit sectors, the dismantling of JLMCs might have begun. To see if this is indeed the case, we repeated the same analysis for establishments in different industries, establishments of firms of differing size, and establishments of firms with and without union. As shown in Figure 4, the proportion of establishments with JLMCs has declined noticeably for mining, services, transportation and communications, and non-union sectors although it is still premature to consider this an early sign of the crumbling of JLMCs for these sectors.

The absence of evidence for the formal dissolution of JLMCs is probably not too surprising since if they decide to end JLMCs, Japanese firms are likely to make them dormant by changing their attributes (for example, reducing the frequency of meetings drastically and trivializing the content of information shared) rather than formally dissolving them. To this end, we created Figures $5-11$ which illustrate whether various attributes of JLMCs have changed from 1988 to 1995 and if so in what way.

Figure 5 shows the average number of JLMC meetings per year in 1988 and 1995. For all

\footnotetext{
${ }^{9}$ This figure is substantially lower than what Kato and Morishima (1999) report. The Ministry of Labour Survey is, however, an establishment-level survey and includes many establishments of small private firms that are not included in the sample universe of the survey conducted by Kato and Morishima (1999). This probably accounts for the discrepancy. Fortunately, the Ministry of Labour Survey also reports the proportion of establishments with JLMCs for establishments of unionized firms that are probably closest to the sample universe of Kato and Morishima (1999). Reassuringly the figures for those establishments were very close to what Kato and Morishima (1999) report.

${ }^{10}$ We recognize that 1995 may be a little too early to detect the full impact of the economic slowdown in the 1990s. As shown in the next section, however, qualitative evidence from our field research of summer of 1999
} 
establishments, the frequency of JLMC meetings fell substantially from 14 times a year to 9 times a year over the time period. It appears that when news is consistently bad, JLMCs meet much less frequently. The figure also points to a considerable difference between sectors. Thus, JLMCs in transportation and communications used to hold JLMC meetings 25 times a year in 1988 while they held JLMC meetings only 11 times a year in 1995. The frequency of JLMC meetings in finance, insurance and real estate has also decreased sharply from 11 times a year in 1988 to only 6 times a year in 1995. JLMCs in larger and unionized firms experienced a sharper drop in the frequency of meetings from 1988 to 1995.

Case histories of Japanese JLMCs suggest that JLMCs tend to function well with the presence of special subcommittees, such as special subcommittee on productivity and special subcommittee on safety and health (Japan Productivity Center, 1990). As Figure 6 shows, the average number of special subcommittees for all establishments has declined somewhat from 3.3 in 1988 to 2.8 in 1995 . Some differences between sectors are also present. Sharp drops have occurred in manufacturing, services, and non-union sectors.

A possible way of weakening information sharing is to undermine the democratic process of selecting employee representatives. In unionized establishments, the democratic selection of employee representatives is typically ensured by union representatives participating in JLMCs as employee representatives. In nonunion establishments, it is normally ensured through election by employees. Figure 7 shows the proportion of unionized establishments with JLMCs in which union representatives participate in JLMCs as employee representatives in 1988 and 1995, and the proportion of non-union establishments with JLMCs in which employee representatives are elected by employees in 1988 and 1995. We failed to find any sign of erosion of the democratic selection of employee representatives over this time period.

The nature of information sharing changes considerably, depending on: (i) the content of information shared (for example, more or less sharing of information on business and strategic plans, such as sales and production plans, and the introduction of new technology/equipment, as compared to labor issues, such as layoffs, working hours, wages and bonuses, fringe benefits, and cultural activities/sports); 
and (ii) the nature of "consultation" (for instance, whether labor representatives are "informed only", or “asked for prior consent"). The Survey of Labor-management Communication selects 16 issues (plus 2 more issues in 1995), such as basic business strategies, corporate restructuring, layoffs, and mandatory retirement, and asks each establishment with JLMCs whether it discusses each of these issues during its JLMC meetings. When the establishment responds positively, it is then asked whether management asks employee representatives for prior consent.

We selected six issues that are of particular relevance to the economic slowdown in the 1990s, especially the recent economic crisis, and created the last four figures. Figure 8 shows the proportion of unionized establishments with JLMCs that discussed each of these six issues (corporate restructuring, hiring and staffing, transfer of employees, layoffs, mandatory retirement, and severance pay/pension) in 1988 and 1995. Figure 9 shows the same figures for non-unionized establishments. Likewise, Figures 10 and 11 show the proportion of union and non-union establishments with JLMCs discussing each of these six issues that asked employee representatives for prior consent in 1988 and 1995.

For both unionized and non-unionized establishments, as shown in Figures 8 and 9, JLMCs are slightly more likely to discuss transfer of employees and layoffs in 1995 than in 1988. For unionized establishments, JLMCs are slightly more likely to discuss mandatory retirement and severance pay/pension in 1995 than in 1988 while they are slightly less likely to discuss corporate restructuring and hiring and staffing in 1995 than in 1988. The opposite pattern is observed for non-unionized establishments. Overall, it is unclear whether JLMCs are more or less likely to discuss issues of topical relevance in 1995 than in 1988.

Nevertheless, when one takes a close look at the nature of consultation on each of these six issues, a noteworthy difference between unionized and non-unionized establishments is revealed. As shown in Figure 10, JLMCs of unionized establishments discussing transfer of employees, layoffs, mandatory retirement, and severance pay/pension are more likely to ask employee representatives for prior consent in 1995 than in 1988. In stark contrast, as shown in Figure 11, JLMCs of non-unionized establishments discussing transfer of employees, layoffs, mandatory retirement, and severance pay/pension are much less 
likely to ask employee representatives for prior consent in 1995 than in 1988. This contrast in the changing nature of consultation over this time period between unionized and non-unionized establishments may suggest that union effectively prevents JLMCs from becoming dormant by keeping the strong consultative role of JLMCs whereas for small to medium size firms with no union, such role may be weakening. As such, union and JLMCs may be complements rather than substitutes. At the same time, it suggests that the overall importance of participation in the Japanese economy may be diminishing with rising proportion of the non-union sector in the economy.

\section{Evolving Practices in the 1990s: Evidence from field research}

In summer of 1999, we conducted field research at a number of Japanese firms. In winter of 1999, we had written them, asking to locate and assemble some specific data on participatory employment practices of their firms, and detailing what kind of questions we intend to ask when we visit them in summer of 1999. In addition to an obvious advantage of field research that more detailed and richer analysis is possible, there is an added advantage. The quantitative data from national surveys are usually not available for the latter half of the 1990s. For example, in the previous section, the lack of available data on JLMCs after 1995 forced us to compare 1988 to 1995 . Conceivably the impact of the economic slowdown in general and financial crisis in particular on JLMCs may be felt only after 1995. Our field research from summer of 1999 provides the most recent picture of employment practices.

We report four cases here, Firm A, Firm B, Firm C, and Firm D. They are all manufacturing firms. The first three cases represent firms that have experienced significant worsening of firm performance and have downsized its labor force substantially in the 1990s. Firms A and B represent two large manufacturing firms. Both are "listed firms" and their shares are traded publicly. Both cases illuminate the resilience of participatory employment practices in general while some subtle changes are also evident. Firm $\mathrm{C}$ represents a medium-size manufacturing firm. It is not listed and their shares are not traded publicly. Here we also see the enduring nature of participatory employment practices. However, we also see a clear attempt by top management to streamline participatory employment practices. 
Unlike the first three firms, Firm D's sales and employment did not fall dramatically in the 1990s although its share price did fall as drastically as the other firms in the same time period. We include our case study of this firm here largely due to unusually rich data on its ESOP we were able to obtain from the firm. The data shed light on the quiet yet important transformation of the scope and nature of the firm's ESOP.

\section{a. Firm A}

\section{$\underline{1 . \text { Site visit }}$}

Firm A is a large manufacturing firm with sales of over 3 trillion yen (nearly half of which is export sales) and employment of close to 40,000 workers in 1998. It is listed in the first section of Tokyo Stock Exchange. The corporation consists of eleven establishments.

On June 10, 1999, we visited the headquarters of the firm. We interviewed our primary interviewee in Personnel (Manager in Personnel Department). The interview lasted about four hours. His young subordinate was also present during the interview and provided some additional information. We had written them several months prior to our visit, asking them to locate and assemble some specific data, and detailing what kind of questions we intend to ask. They did take our request very seriously and spent a lot of time and effort to prepare confidential data for us.

On the next day, we visited Establishment $\mathrm{P}$ of this firm and spent over half an hour observing a number of shopfloors of this establishment. We then interviewed a foreman who is in charge of a section (called kakari). He reports to department chief (kacho) and has six unit chiefs (kocho) reporting to him. Each unit consists of about 10 to 15 workers. He spent over thirty years in this department and was just about to be promoted to kacho. The interview lasted a little over an hour, focusing on shopfloor committees and small group activities.

On June 16, 1999, we visited Firm A's union headquarters, and interviewed our primary interviewee (Vice President of the union) for about two hours. We were also given an opportunity to interview his young staff members (full-time union officials) for a little over an hour. Our primary 
interviewee is the union's No. 2 person and does attend all HQ-JLMCs. Our secondary interviewees work very closely for him and engage in day to day activities of JLMCs. Several months prior to our visit, we had also written them a similar letter to what we had sent to our personnel interviewees, asking them to locate and assemble some specific data, and detailing what kind of questions we intend to ask. They too took our request very seriously and prepared confidential data for us.

\section{$\underline{\text { 2. Background }}$}

Figures 12 and 13 summarize changes in key characteristics of Firm A for the last two decades. All nominal variables such as sales, total labor cost, labor productivity (value added per employee), capital labor ratio, are converted to real variables by using appropriate price indices. Labor is the total number of employees and share price is the annual average price of stock. All variables in Figure 12 are relative to their 1982 levels. We also calculated standard accounting firm performance measures such as ROA and $\mathrm{ROE}$ as well as shareholder returns (a standard economic firm performance measure). It is obvious from the tables that in the 1990s the firm's performance worsened and became more volatile. It cut 30 percent of its labor force throughout the 1990s from about 57,000 to about 40,000. This downsizing was accomplished mostly by a combination of limited hiring and transfers of workers to related firms without laying off workers. The firm hired over 3,000 college and high school graduates right after their graduation in 1990. In the next three years, the firm continued to reduce this new graduate hiring, and hired about 2,000 in 1993. New graduate hiring was extremely restrained in the next four years ranging from 482 to 62. The new graduate hiring level did bounce back somewhat in 1998 and 1999, reaching the 1,000 level.

As shown in Table 1, about 2,000 employees were transferred to related firms, sales firms and other firms each year on a fixed year term (typically two years term) for 1995 and 1996. The level of temporary transfer has declined to 1,000 recently. Some of those on temporary transfer were changed to be permanently transferred. Six hundreds to seven hundreds workers were permanently transferred each year 
for the last four years except for the most recent year when the firm experienced a substantial reduction in the number of permanent transfers. These numbers suggest that roughly 30 percent of those on temporary transfer never returned to the firm and became permanently transferred. Almost all employees on transfer were over 50 years old and white-collar workers. The majority of transfers are to the firm's related firms, including its sales firm. The firm pays each worker who is permanently transferred a severance pay which amounts to five years of his/her annual earnings. Permanent transfers do present some shopfloor morale problem. Some employees complain: "I wished I could have remain in Firm A and have attended my daughter's wedding as a proud employee of Firm A.” Being an employee of a famous and prestigious company like Firm A means a status quo. Though making sense financially to be transferred permanently, many employees accept permanent transfer with some mixed feelings.

In addition, the firm used a special early retirement incentive pay during 1995 and induced over 4,000 early retirements during the year. At age 30, an early retiree was offered 12 months of monthly pay; at age 40,18 months; at age 50,48 months; at age 58, 3 months. The firm is again using a similar early retirement incentive pay currently.

In the process of this downsizing, the amount of work has not been declining as fast as the number of employees. To cope with this overloading of existing full-time regular employees, the firm has increased the number of part-time employees. In January of 1994, the firm had 64 part-time employees. In January of 1999, the firm had 123 part-time employees. 82 of them (67 were female) were engaged in clerical and other white-collar work whereas 36 of them (33 were female) were engaged in simple manual task to assist regular production workers (such as moving materials); and 5 actually worked as production workers.

\section{HQ-JLMCs}

Headquarters-level JLMCs (HQ-JLMCs) existed at least in 1955. Initially HQ-JLMCs were functioning as a mechanism for management to explain their decision ex post to union representatives. However, in part 
due to a charismatic and aggressive union leader, by 1985, HQ-JLMCs had changed its role from information sharing to joint decision making. For example, during HQ-JLMCs meetings, union representatives tried to veto management decision to open a new plant overseas. Following the resignation of the union leader in 1985, the join-decision making aspect of HQ-JLMCs was significantly reduced in 1986, and the current form of HQ-JLMCs was established.

HQ-JLMCs consist of five types of meetings: (i) management council meetings; (ii) committee meetings; (iii) restructuring meetings; (iv) production meetings; and (v) individual item meetings. At management council meetings, six to seven top managers (CEO, vice-CEOs, and director of personnel) meet with six to seven top full-time union officials regularly. Each meeting lasts half a day. Business strategies and plans, current status of corporate performance are discussed. The management council meetings are held normally twice a year. They are scheduled right before Spring Wage Offensive and Fall collective bargaining so that they can help facilitate each collective bargaining. There has not been any major change in the basic framework of HQ-JLMCs in the 1990s.

Union begins its preparation for management council meetings a month prior to the meeting. A full-time union official visits various shopfloors and talks to union representatives of establishments to find out what union members are concerned about and what they want to know from management. This is very time- and effort-consuming. Based on this field research, he writes up a list of questions. It is imperative to have careful field research to gather information from shopfloors. For example, careful field research at shopfloor level revealed that in spite of management's overall decision to reduce a number of products it sells, it was not really happening although it looked as if it was happening on paper.

A list of questions are then given to management seven to ten days prior to the meeting. Management then prepares responses to those questions. At the management council meeting, management presents an answer to each question and then union further asks questions about the answer. After the meeting, both management and union prepare separate proceedings and exchange each other's proceedings before dissemination. Some information shared during meetings is designated as confidential and is excluded from the proceedings. Union proceedings are distributed to all union members and 
management proceedings are distributed to all managers.

HQ-JLMCs have a number of sub-committees, including sub-committee on production, subcommittee on employee benefits and welfare, sub-committee on sales, and sub-committee on development. Sub-committee meetings on production are held regularly twice a year and are attended by six to seven managers from production department, domestic sales department, export sales department, and personnel department, and six to seven top full-time union officials. Biannual production and staffing are discussed. In addition to production sub-committee meetings, occasionally other sub-committee meetings such as sub-committee on employee benefits and welfare,, sub-committee on sales, sub-committee on development, are also held.

Restructuring meetings are held on an ad hoc basis. Decentralization, outsourcing, and plant closures are discussed. Production meetings are also held on an ad hoc basis. ${ }^{11}$ While during committee meetings on production the basic framework of employment adjustment such as worksharing is discussed, production meetings deal with changes in such framework in response to change in output demand. Individual item meetings are held also on an ad hoc basis to discuss items other than what is covered in other meetings.

\section{$\underline{3.1 \text { Content of Information Shared }}$}

There is no evidence for reduction in the quantity of information shared through HQ-JLMCs in the 1990s. First, there has been no apparent decline in the frequency of meetings in the 1990s. As shown in Figure 14, the total number of HQ-JLMCs meetings reached twenty meetings a year in 1992 and kept exceeding twenty till 1995. The number fell a little for the next three years. This is somewhat consistent with our national survey finding of a declining meeting frequency from 1988 to 1995 as presented in the previous

\footnotetext{
${ }^{11}$ Our primary union interviewee and personnel interviewee provide me with slightly conflicting views on production meetings. According to our personnel interviewee, they are held regularly on a monthly basis. According to the data provided by our union interviewee as shown in Figure 14, there were 14 production meetings in 1998. As far as 1998 is concerned, they were indeed held monthly (actually slightly more often than monthly).
} 
section. However, in 1998, it reached all-time high level of fifty one meetings a year. Most of the increase came from restructuring meetings and production meetings. Management council meetings and subcommittee meetings on production stayed pretty much the same over this period.

To be consistent with this increased frequency of meetings, our union interviewee feels that the amount of information shared during HQ-JLMCs has increased in the 1990s. Our personnel manager interviewee notices that union has been increasingly concerned about basic business strategies questions which only CEO and CFO can answer. Consequently, the information shared during HQ-JLMCs has become more on business strategies as opposed to more direct labor-related issues (such as employee welfare and benefits) and can be said more "confidential". Our personnel interviewee adds that naturally discussion on restructuring such as decentralization, outsourcing, plant closures, selling off a segment of its business has increased in the last few years. This is reflected in an increase in the number of restructuring meetings in the last few years.

Our union interviewee believes that the quality of information shared has also risen in the 1990s. In the 1970s and 1980s, news was almost always good. Wages and bonuses were rising faster than its major competitors. There was very little concern about firm performance, wages and bonuses and employment security among employees. The quality of information shared during HQ-JLMCs was not of prime concern. In the 1990s, firm performance has worsened; annual raise of wages and bonuses has stagnated; and employees have been more concerned about their employment security. The quality of information shared has become of major concern. Our primary union interviewee says, "When the rank and files are asked to accept zero increase in bonus, for example, they do demand a detailed and convincing justification."

Our primary union interviewee believes that some of the information he receives from top management can be considered "insider information" and that top management does ask him not to release to other union members. To maintain a good relationship with top management, he does keep such 
information in strict confidence. Our secondary union interviewees echo this by saying that most information is shared with them before becoming public knowledge and that it would be possible to use some of the information shared during HQ-JLMCs to make money in the stock market (in other words, some of the information shared during HQ-JLMCs could be insider trading material.) They quickly add that they do not engage in such activities.

\subsection{Nature of Participation}

During management council meetings and sub-committee meetings on production, management explains and union asks questions. Union receives detailed explanations from management on business strategies and plans (including investment, opening and closing of plants, sales and production plans, introduction of new products) during management council meetings and committee meetings on production. Union asks questions, in particular asks for justifications for these plans but do not try to change the overall framework of the plans. Our primary union interviewee states plainly, "We do not have any right to change these plans. We do not have any intention to decide on basic business strategies jointly with management." As a result, it is rare for union representatives to offer alternative plans to management insofar as basic business strategies are concerned. Nonetheless, union representatives sometimes offer ideas about what kind of products may sell. Our personnel interviewee recalls that union representatives suggested that some redundant factory workers would support sales department by handing out sales ad fliers.

However, when they discuss the consequences on employees of these business strategies and plans during restructuring meetings, production meetings and individual item meetings, they decide jointly with management. For example, plant closures and outsourcing were proposed several years ago from top management to union representatives during their management council meetings. Although they did ask many detailed questions about why they were necessary, they did not try to change the decision to close the plant and outsource. Instead, they successfully negotiated with top management during restructuring meetings to delay the plant closure for several months and get favorable conditions for those employees 
who are transferred as a result of the plan closure and outsourcing. For example, when employees are transferred to subsidiaries, they usually face poorer working conditions, such as lower wages and longer working hours. Union negotiated hard during HQ-JLMCs meetings to set up a policy of minimizing changes in working conditions as a result of transfers to subsidiaries.

In the 1990 s, in response to worsening firm performance, however, discussion on basic business strategies and plans between management and labor has become more extensive and intensive. Union tends to ask more and harder questions on basic firm performance and business strategies, such as "why a certain product is not selling;" "why the firm has so much debt." This reflects an increased interest and concern in the overall firm performance and hence employment security among employees.

\section{$\underline{3.3 \text { Employee Interest }}$}

In the 1990s, interest in HQ-JLMCs and information shared during HQ-JLMCs meetings among employees has clearly increased. Participation in union meetings has increased. For example, white-collar union members at the headquarters are traditionally somewhat apathetic to union newsletters which union uses to disseminate the information shared at HQ-JLMCs. In the last few years, they have started to read union newsletters more often and more carefully.

\subsection{Relationship between Collective Bargaining and HQ-JLMCs}

Our field research revealed that there are two kinds of complementary relations between collective bargaining and HQ-JLMCs; (i) complementarity in scope; and (ii) complementarity in time. According to the complementarity in scope model, collective bargaining deals with wages, bonuses, working hours and agreement revision whereas HQ-JLMCs deal with all other items. Thus, depending on an item to be discussed, either HQ-JLMCs or collective bargaining will be used. According to the complementarity in time model, all items will be discussed first at HQ-JLMCs and collective bargaining will be used only when HQ-JLMCs cannot resolve differences between management and labor. Firm A subscribes to the 
complementarity in scope model.

\section{Establishment-JLMCs}

At each of 11 establishments, once a month five top managers (plant manager and managers of relevant departments) meet with an establishment representative of union and a few other full-time union officials. The main objective of these Establishment-JLMCs is to review last month's production plans and achievements and go over next month's plans for the establishment. In addition, twice a year they meet to discuss biannual productions plans. Transfers of workers between lines within the establishment are discussed here. Union representatives receive detailed explanations from management about why transfers are necessary. Union representatives do not try to reverse management decision to transfer workers but the number of workers transferred may be revised as a result of discussion between labor and management during establishment-JLMCs. Most remarks made on changes in HQ-JLMCs in the 1990s also apply to Establishment-JLMCs.

\section{SFCs (Shop-Floor Committees)}

There are over 400 shop-floors (each shop-floor consists of about 50 to 100 employees). The firm used to have no formal standing SFCs although upon request from union, each shopfloor held committee meetings occasionally. In spring of 1996, union felt need for better communication at the shopfloor level, and requested the firm to establish more formal standing SFCs and hold regular meetings. Management and union jointly decided to establish more formal SFCs and hold regular meetings ( 3 to 4 times a year for white-collar shopfloors and once a month for blue-collar shopfloors as a target). Since then, union has been gathering monthly data on the incidence of meetings at each shopfloor. As shown in Table 2, for the last two years, the average SFC met four times a year. The incidence of meetings is, however, far from uniform. Our union interviewee remarks that there are negative correlations between the number of SFC meetings and the number of shop-floor complaints made to upper-level union organizations. 
SFCs have two functions: (i) resolving shopfloor-level work conditions issues, such as airconditioning, smoking/non-smoking environment, bath rooms, taking paid vacation, cafeteria menu; and (ii) explanation of shopfloor production plans and related staffing issues by a manager in charge of the shopfloor. The link between Establishment-JLMCs and SFCs is strong. First, what is not resolved at SFCs goes up to Establishment-JLMCs. For example, labor representatives requested the introduction of air-conditioners to its shopfloor during shopfloor committee meetings. However, a manager in charge of the shopfloor did not have the budget to pay for them. The issue was discussed at the next EstablishmentJLMCs and top management of the Establishment decided to purchase several spot air-conditioners for the shopfloor. Second, SFCs discuss shop-floor production plans which are derived from establishment production plans that are discussed during Establishment-JLMCs.

The meetings are held outside of regular working hours and they usually last one to two hours. More time is usually spent on the first function of resolving shop-floor work condition issues than on the second function of discussing shop-floor plans.

Our union interviewee as well as my personnel interviewee recognize the benefit of SFCs and its increasing importance in the future. Employees are generally interested in SFC meetings. However, if SFCs fail to produce concrete results such as satisfactory resolution of air-condition request from employees, employees tend to lose interest in SFCs.

Our personnel interviewee considers the benefit of SFCs quite substantial. Complaints that are resolved at SFCs are not really earth-shattering but when they are resolved, employees can actually see, feel and touch the results and their morale will be enhanced.

Grievance procedures deal with personal complaints that can not be expressed in public. For example, those who feel their bosses give them unfairly low subjective performance evaluations never voice their complaints during SFC meetings but submit their complaints to grievance committees.

Our personnel interviewee stresses the importance of manager's ability to communicate in successful SFCs and that some SFCs do not function well due to the lack of manager's ability to listen to 
labor representatives. When managers lack the ability to listen, SFCs become an extension of regular supervisor-supervisee relationships and labor representatives do not feel at ease to express their views, and hence SFCs stagnate.

Establishment P holds its SFC meetings at the section level (about 500 employees). Section Q holds a meeting regularly on a monthly basis off hours. It usually lasts one hour. In addition, upon request from union representative of the section, additional meetings can be held. During the previous year, Section Q held two meetings a month on average. Our foreman interviewee adds that it was an unusually busy year in terms of SFCs.

The section chief and all foremen attend. Union representatives of the section will attend. Once a month union representatives of the section hold a meeting of union representatives of kakari and prepare for their SFC meeting for that month. Three days prior to the meeting, a written list of suggested discussion topics are given to the section chief. Work environment issues such as shower rooms, water leaks, smoking, bathrooms, cafeteria, air-conditioning are of central concern for their SFC meetings. There is no discussion on production plans at the section-level. This is somewhat different from what our personnel and union interviewees explain. The operation of SFCs is left to each shopfloor and there seems to be quite a variation in the actual operation of SFCs among various shopfloors. There has not been any major change in SFCs at this section in the 1990s.

\section{SGAs (Small Group Activities)}

The firm currently has 2,090 QC circles, amounting to 10.6 employee per circle. In 1965, the first QC circles were registered in Establishment P. Since then, QC circles have been established at each new plant upon its opening. Union is neither negative nor positive about these small group activities. Part-timers are not included. The firm maintains the voluntary nature of QC circles. Thus, activities are held after hours and there is no compensation for those hours. Not all employees volunteer to participate. Older employees approaching their retirement tend not to participate. Our personnel interviewee spent two and a half years 
as a plant-level personnel manager and did not recall any sign of stagnation of QC circle activities over time. One reason for the overall absence of stagnation of SGAs is that employees are generally very proud of the success of their groups. When their group wins the annual QC circle contest, they usually have a major celebration and are extremely proud of their group. The sense of pride seems to be carrying them through over the last three decades. Our personnel interviewee is somewhat concerned about the future of SGAs since it is uncertain whether new generations of Japanese workers can continue to participate wholeheartedly in SGAs largely for their sense of group pride.

However, most recently, plants have not been too busy and QC activities have been somewhat stagnant. Our personnel interviewee argues that when plants are not busy, possible sources of productivity and product quality improvements tend to be hidden. SGAs for white-collar occupations have not been as active and successful as those for blue-collar occupations.

Neither our personnel interviewee nor union interviewee is aware of any relationship between SGAs and SFCs. As a result of aging of the labor force which was accelerated by limited hiring in the last few years (the average age of employees at this firm rose from 37 to 40 in the last decade), transmitting the skills and ethos of SGAs to the next generation is increasingly becoming a major concern.

We were very fortunate to be able to spend half a day in Establishment $\mathrm{P}$, observing the actual operations of shopfloors and QC circles and interviewing a veteran foreman. The smallest organizational unit of Establishment P is called "han". Each han consists of 15 to 20 employees, and "kocho" is in charge of each han. In addition to kocho, each han normally has one to two "shidoin" and four "leaders". Each "leader" is in charge of one of the four main objectives: (i) safety; (ii) high quality; (iii) cost reduction; and (iii) punctual delivery. Each leader will carry out various activities to achieve its assigned goal. These activities may take a form of SGAs. At any rate, all these activities are not voluntary, fully directed by kocho, and are part of work, and hence are done normally during regular hours. On the other hand, QC circles are voluntary, and depending on the project, it will change its QC captain who is not necessarily a "leader" (people with one year of tenure can and will become QC circle captain). Projects are also chosen by circle members with some indirect guidance from kocho. Each QC circle carries out six to twelve 
projects a year.

On average, each QC circle meets 4 to 6 times a month and each meeting lasts one to one and half an hour. Sometimes, for other activities such as safety, cost reduction, punctual delivery, each employee spends two to three hours a month after regular hours. All these after-hours activities are considered voluntary and thus without pay. In addition, for a couple of hours a month, on average, employees are also engaged in machine maintenance kaizen activities after hours. For these activities, they are paid at an overtime premium rate. Each employee's performance in all these activities including voluntary QC circles is evaluated by kocho.

Our foreman interviewee believes that QC circle activities are more active and more voluntary than ten years ago. For example, in the 1980s, the firm used to provide some modest compensation for QC activities. However, in the 1990s, the firm abolished this QC circle compensation and made it clear that QC activities are voluntary. Both quantity and quality of QC activities have increased substantially in the 1990s. To meet increasing needs for more technically sophisticated projects and quick turn around time, the firm introduced a special full-time kaizen group (a handful of veteran workers) who can perform some experiments for various ideas of QC circles. He attributes this rise in the quantity and quality of QC activities to the increased competition and sense of crisis among employees. "Our means for living have been threatened by the increased competition and if we do not produce a better and cheaper product, we will lose out". In other words, employee interest in SGAs has clearly increased. Our foreman interviewee strongly believes that ideas for improvement have not been exhausted.

\section{$\underline{\text { 7. ESOPs }}$}

Firm A has a standard ESOP with 5 percent subsidy from the firm. The ESOP participation rate (proportion of the labor force participating in an ESOP) remained around 30 percent in the 1980s. The firm embarked on a major ESOP promotion campaign during 1987, and as a result the ESOP participation rate jumped to 70 to 80 percent. Since then it has been falling steadily and it is currently a little below 50 
percent. As shown in Figure 12, the share price of the firm is one third of what it was in 1989. Many employees who joined the ESOP during the firm's ESOP promotion campaign in 1987 are experiencing substantial capital loss. For 1998, the firm experienced over 1,000 employees exiting from the ESOP for reasons other than separation from the firm and only 204 people joined the ESOP.

The initial objective of the ESOP was threefold: (i) enhancing the sense of participation and motivating employees; (ii) providing a source of retirement income; and (iii) acquiring a stable shareholder group. With substantial capital loss in the 1990s and highly volatile share price in recent years, our personnel interviewee feels that the ESOP's ability to achieve its objectives has diminished in the 1990s. The average contribution of participants is 5,000 to 10,000 yen from monthly pay and 20,000 to 30,000 yen from bonus.

\section{PSPs (Profit Sharing Plans)}

There is no formal PSP in the firm. However, firm performance has been a major factor in each year's bonus negotiation between the firm and union since late 1980s. As a result, there is a strong positive correlation between the amount of bonus payment and firm performance. There is no gain sharing. Limited only for managers, several years ago there was a proposal to introduce gain sharing but it has not been implemented. Our personnel interviewee suggests that the firm will plan to strengthen the link between firm performance and employee pay.

\section{b. Firm B}

\section{$\underline{\text { 1. Site visit }}$}

Firm B is a large manufacturer with sales of a few trillions of yen (about one quarter of which is export sales) and employment of close to 20,000 workers in 1998. It is also listed in the first section of Tokyo Stock Exchange. The firm has over ten establishments. On May 26, 1999, we visited the headquarters of the firm. We interviewed our primary interviewee in Personnel (General Manager, Labor Relations, 
Personnel\&Labor Relations Division) first. The interview lasted about three hours, including lunch. After lunch, we interviewed our secondary interviewee in Personnel (Manager, Labor Relations) for an hour and half. Like in the case of Firm A, we had written them several months earlier, asking them to locate and assemble some specific data, and detailing what kind of questions we intend to ask. They did take our request very seriously and prepared a variety of in-house data for us.

After our visit to the headquarters, we visited the headquarters of Firm B' union and interviewed our union interviewee (General Secretary, No. 2 in the union organization). The interview lasted over one hour. Several months earlier we had also written him a similar letter to what we had sent to our personnel interviewees, asking them to locate and assemble some specific data, and detailing what kind of questions we intend to ask. They also worked hard to prepare in-house data for us.

\section{$\underline{\text { 2. Background }}$}

Figures 15 and 16 summarize changes in key characteristics of Firm B for the last two decades. Firm performance continued to worsen in the 1990s. It cut almost 50 percent of its labor force throughout the 1990s. This downsizing was accomplished mostly by a combination of limited hiring and transfers of workers to related firms without laying off workers.

\section{HQ-JLMCs}

HQ-JLMCs existed at least in 1970. HQ-JLMCs consist of two types of meetings: (i) management council meetings; and (ii) labor-management committee meetings. Management council consists of a group of top management (CEO, vice-CEOs, and other directors) and a group of ten full-time union officials at the headquarters. There are two biannual council meetings and four quarterly council meetings a year at the headquarters level. CEO and vice CEOs attend biannual meetings which meet right at the biannual accounting report time while they do not attend quarterly meetings. Union representatives from each establishment also attend these biannual council meetings. Each meeting normally begins at $11 \mathrm{a} . \mathrm{m}$. and ends at 5 p.m. with an informal luncheon. Management explains its production plans, introduction of new 
equipment, temporary and permanent closing of plants and equipment, and major organizational changes. Union asks for their justifications.

Labor-management committee consists of director of personnel and his/her subordinates and a group of ten full-time union officials at the headquarters level. The committee meets on an ad hoc basis. Depending on the issue, full-time union representatives of relevant establishments may attend these committee meetings. Management explains staffing changes as a result of new production plans, such as worksharing; layoffs; substantial transfers of employees; welfare benefits, fringe benefits; and health and safety. Union negotiates with management on these issues.

Management council meetings and labor-management committee meetings are complementary. For example, plant closure plan is proposed to management council meetings and union asks for its justification there. Labor-management committee meetings work out an agreement on the size and conditions for labor transfers as a result of the plant closure. There has not been any major change in the basic framework of HQ-JLMCs.

\subsection{Content of Information Shared}

Our primary personnel interviewee strongly objects to a popular notion of weakening JLMCs by arguing that both the quantity and the quality of information shared during JLMCs meetings have increased in the 1990s. "When things are going well, it may not be crucial to have a good labor-management relationship. However, when the firm is faced with serious competition, it is imperative to have a good labormanagement relationship and make decision, based on good discussion between labor and management."

To be consistent with his remarks, there has been no indication of a decline in the frequency of JLMC meetings. As shown in Figure 17, we see no downward trend in the total number of JLMC meetings in the 1990s. Please note that the number for management council meetings and labormanagement committee meetings include establishment-level meetings as well as headquarters level meetings and therefore that they tend to be quite high.

We were given a unique opportunity to study their most recent proceedings of biannual 
management council meeting and those from ten years ago. These proceedings are distributed to union representatives from each establishment. Those from ten years ago were very detailed and close to a word to word transcription of the actual meetings. In stark contrast, more recent proceedings were less detailed and close to an executive summary. According to our union interviewee, compared to ten years ago, the firm is facing a much more competitive environment and union members are much more concerned about firm performance and their employment and earnings. To reflect these changes, union's needs for deeper information about firm performance, business strategies and plans have risen substantially. As a result, union has been asking more and deeper questions during JLMC meetings, and therefore has been acquiring deeper and more detailed information about firm performance, business strategies and plans. Word to word proceedings of such meetings might lead to leaking of some confidential information. Also, he suggests that union is looking for more than superficial answers to their questions from management and that management tends to be more forthcoming when they know that their words are not going to be published in the proceedings.

In parallel to this increased quality and quantity of information shared during JLMCs, union more often than before offers alternative plans.

\section{$\underline{3.2 \text { Nature of Participation }}$}

During management council meetings, management explains its production plans, introduction of new equipment, temporary and permanent closing of plants and equipment, and major organizational changes. Union asks for their justifications. Labor-management committee meetings deal with more direct labor issues such as staffing, worksharing, transfers, layoffs, benefits. Naturally, union is often asked for its views on various issues and union sometimes offers alternative plans. According to collective agreement, unlike collective bargaining which deals only with wages and changes in collective agreement, management may implement its plans even if no agreement is reached with labor. However, our primary personnel interviewee reports that management rarely has to resort to this clause in order to implement its plans. He offers two reasons. First, union is very well-informed about the competitive environment for 
the firm, and its overall understanding of the current market condition is close to the one of management. Second, management and top union officials engage in extensive informal communication prior to HQJLMC meetings and actual plans proposed by management to various formal meetings often have already been modified to incorporate union input. If union objects strongly to management plans, rather than resorting to management's right to implement without an agreement, management is likely to withdraw its plans. Our union interviewee confirms the above point.

\section{$\underline{3.3 \text { Employee Interest }}$}

Our primary personnel interviewee feels that union is taking JLMCs more seriously, and that union's needs for getting good information at JLMCs and understanding it and explaining it well to its union members are increasing in the face of increased competition. This point is confirmed by our primary union interviewee. In the 1990s, interest in HQ-JLMCs and information shared during HQ-JLMC meetings among employees has clearly increased. Employees are more sensitive to firm performance and competitive environment.

\subsection{Relationship between Collective Bargaining and HQ-JLMCs}

Like in the case of Firm A, Firm B subscribes to the complementarity in scope model.

\section{Establishment-JLMCs}

Establishment-JLMCs are similar in structure to HQ-JLMCs. They have two types of meetings: (i) management council meetings; and (ii) labor-management committee meetings. Management council consists of a group of top management at the establishment level and a group of full-time union officials at the establishment level. There are four council meetings a year at the establishment level. Management explains its quarterly production plans, introduction of new equipment, temporary and permanent closing of plants and equipment at the establishment level. Union asks for their justifications.

Labor-management committee consists of director of personnel and his/her subordinates and a 
group of full-time union officials at the establishment level. Unlike labor-management committee at the headquarters level, labor-management committee at the establishment level meets regularly and frequently (twice a month). Management explains staffing changes within the establishment as a result of new production plans, such as worksharing; layoffs; substantial transfers of employees; welfare benefits, fringe benefits; and health and safety. Union negotiates with management on these issues. There has not been any major change in the basic framework of Establishment-JLMCs in the 1990s. Most remarks made on changes in HQ-JLMCs apply to Establishment-JLMCs.

\section{SFCs}

At the plant level within each establishment, plant manager and his/her subordinates (about ten managers) meet with a union representative of the plant and other union representatives (about ten people) once a month. They discuss shop-wide production plans, and introduction of new equipment and temporary and permanent shut-down of equipment. General employee interest in shopfloor committees is always quite

high. Establishment-JLMCs and SFCs are well-coordinated so that establishment-wide plans are consistent with plant-wide plans.

\section{SGAs}

The firm has a long history of SGAs, dating back to 1962. The firm outlines its SGAs as follows

- To organize voluntary group activities by employees in equal positions and on the basis of each employee's voluntary participation.

- To select themes at each job site, and to attain goals.

- To realize each employee's self-fulfillment in his job through improvement of ability and demonstration of creativity.

- To respect fellow employees, and to create an energetic job site with a happy atmosphere.

- To contribute to the development of the company's businesses through SGA, thereby contributing to society. 
According to the statistics provided by the firm, there is no evidence for stagnation of SGAs in the 1990s. As shown in Table 3, the total number of SGA groups has declined from close to 4,000 in 1992 to close to 2,500 in 1997 as the firm has downsized its labor force. However, since the number of SGA groups has not fallen as fast as the total number of employees, employees per group (dividing the total number of employees by the total number of SGA groups) has decreased during this time period.

The total number of projects completed during each year has also diminished from 22,000 in 1992 to 16,000 in 1997 . Nonetheless, the number of projects completed per group has actually risen from 5.86 to 6.40 since the total number of SGA groups has fallen faster than the total number of projects completed. The proportion of blue-collar workers who participate in SGAs has been stable around 95 percent except for 1994. In short, in the 1990s, there was no sign of either declining employee participation rate in SGAs or diminishing number of projects completed by each group. We failed to obtain any systematic data on the quality of the projects over time.

\section{ESOPs}

Firm B introduced its ESOP in September of 1988, which is unusually late compared to its competitors who introduced their ESOPs in the 1970s. During the first year of its ESOP, over 4,000 employees signed up for it. However, only 800 employees joined during the next two years. To boost the ESOP membership, the firm introduced a 5-percent subsidy in 1993. Close to 1,500 employees joined during that year. However, since then, on average, fewer than 100 employees joined each year. Currently, only about 10 percent of the labor force in the firm participate in its ESOP and 0.2 percent of the total number of outstanding shares are owned by its ESOP. As shown in Figure 15, the share price of the firm is one quarter of what it was in 1989. Many employees who joined the ESOP during the firm's ESOP introduction year are experiencing substantial capital loss. Our primary personnel interviewee attributes the firm's low ESOP participation rate to a combination of rapidly falling share price and falling income of employees. 


\section{PSPs}

The firm had a long history of collective incentive pay scheme. The amount of pay was determined by annual increase in physical productivity. Higher physical productivity used to mean higher profitability due to stable output prices. However, in the 1990s, due to falling and unstable output prices, higher productivity does not necessarily mean higher profitability. Thus, this collective incentive pay scheme was abolished in 1997. Since then, the firm has been placing more emphasis on individual incentive pay, in particular for managerial and professional employees.

\section{c. Firm C}

Firm $\mathrm{C}$ is a medium-size manufacturing firm with sales of 150 billion yen and employment of over 2,000 workers in 1997. It is not publicly traded. The firm has five establishments. On June 23, 1999, we visited the headquarters of the firm. We interviewed the president of the firm's union. He has been the president over twenty years. The interview lasted about two hours. After that, we interviewed our interviewee in Personnel (Manager, Personnel Department) for about an hour. We had written them a few weeks prior to our visit, asking them to locate and assemble some specific data, and detailing what kind of questions we intend to ask. They worked diligently to prepare in-house data for us. We present this case mostly to contrast the situations with medium-size unlisted firms to large listed firms, and show some important similarities and differences between large listed firms and medium-size unlisted firms.

Figures 18 and 19 summarize changes in key characteristics of Firm $\mathrm{C}$ for the last decade. Firm performance clearly worsened in the 1990s. Inflation-adjusted real sales peaked in 1990 and then continued to fall till 1994 when real sales were almost a half of the 1990 level. Since then, recovery of real sales has been sluggish at best. Real net profit (after tax), ROA and ROE continued to decline in early 1990s and experienced negative profit two years in a row (until this time, the firm had never experienced negative profit since its founding in 1945). Since then, recovery of profitability has been still rather weak. The firm began downsizing its workforce in 1993 and by 1997 the firm's employment became almost 80 percent of its 1992 level. 
The firm has JLMCs only at the headquarters level. JLMCs began in 1970. However, till 1978, JLMCs held informal meetings three or four times a year in which labor and management exchanged ideas with no specific agenda. JLMCs were formalized in 1978, with specific agenda set for each meeting. In the 1990s, they started to hold meetings regularly once a month. In addition, upon request from either management or union, JLMC meetings can be held on an ad hoc basis. In fact, to discuss the present issue of permanent transfers of workers to related firms, one of those ad hoc JLMC meeting was scheduled in the afternoon of our visit to the firm. Each meeting lasts four hours.

Unlike in the case of large, listed firms, top management of this firm is currently proposing to reduce the frequency of JLMC meetings and shorten the length of each meeting from four to two hours. Top management is arguing that this proposed change is necessary for more efficient and timely management. Our union interviewee is skeptical about this proposal. He fears that this might make JLMCs more superficial. Based on his twenty-year experience with JLMCs, he argues that only with ample time for discussion, important information is often revealed during JLMCs.

Regular participants in JLMC meetings from management side include vice-CEOs, other executives and director of Personnel (6 to 7 executives in total). CEO used to attend all JLMC meetings before 1990. However, with union's suggestion, since 1990, CEO attends only a couple of meetings a year when wage negotiation is complete. Depending on the agenda items, top management of the relevant establishments also attends. Regular participants from union include union officials at the headquarters level and union representatives from each of the five establishments (10 to 12 officials in total).

Regarding the relationship between collective bargaining and JLMCs, the firm and union used to subscribe to the complementarity in scope model. However, in the 1990s, with union's suggestion, it switched to the complementarity in time model. In other words, all items including typical collective bargaining items such as wage now go to JLMC meetings, and only when JLMC meetings fail, collective bargaining is used. Our union interviewee feels that JLMCs are sufficient to resolve almost all issues. In addition, occasionally, sub-committees are formed to discuss specific issues. For example, currently they have one sub-committee on the issue of extending mandatory retirement age from 60 to 62 . 
Unlike in the case of large listed firms, most of the time, union does not tell management in advance what kinds of questions they will ask. However, when either management or union has a particularly important issue, the issue will be discussed prior to JLMC meetings between director of Personnel and top union officials at the headquarters level. By the time an actual proposal is submitted to JLMC, it would have been already revised to incorporate union input.

During each monthly JLMC meeting, management presents and explains monthly data on orders, sales, production, and sales profit for each establishment. Occasionally, management does share some very confidential information, such as development of new products and opening and closure of plants, with union officials during JLMC meetings. Management asks union officials to keep such information in confidence. Since JLMC meetings were formalized in 1978, there has not been any incidence of confidential information leaking to outside of the firm. Our union interviewee feels that he has developed a good, trust relationship with management, and that management does not hide confidential information from him.

Union occasionally proposes alternative plans to management on business strategies. For example, in the 1970s, the firm introduced a new product. However, the new product continued to yield loss, and management proposed to drop the product during JLMC meetings. Union suggested not to drop the product and volunteered to accept lower wage for a couple of years in order to keep the product alive. Management accepted union's offer and decided to keep the product. In a few years, the product started to yield profit.

About 15 years ago, management decided to shift its headquarters' production facility to one of its establishments. Through JLMC meetings, union asked management to delay the timing of shift in order to make transfers of workers from the headquarters to the establishment more smooth. Management agreed and delayed the change.

Management does not always accept union's suggestions. For example, in late 1980s, management decided to introduce a new product against union's objection. However, it is only occasional that union makes suggestions on management matters such as introduction of a new product, opening and 
closing of plants. Most discussion during JLMC meetings is centered around employment issues arising from these management decision, such as the number of transfers of employees and conditions for those on transfer when management's business strategy requires such transfers.

Unlike the case of large listed firms, the firm has neither establishment-level JLMCs nor SFCs. Our union interviewee argues that HQ-JLMCs function as establishment-level JLMCs by including union representatives from each establishment. In fact, establishment-wide issues are raised by union representative of the relevant establishment during HQ-JLMCs.

Twice a year, top management and top union officials visit each plant and check health and safety. However, many shopfloor issues including not only health and safety but other work environment issues such as air-conditioning are raised during these visits. In some sense, again, HQ-JLMCs function as SFCs. Recently, top management has suggested to reduce the frequency of these visits from twice a year to once a year in order to achieve more efficient and cost-effective management.

In the $1970 \mathrm{~s}$ and $1980 \mathrm{~s}$, JLMC meetings tended to focus on the distribution of an ever increasing pie to labor, such as building a new facility for employee welfare. In the 1990s, JLMC meetings tend to focus on restructuring and downsizing.

Our union interviewee does not believe at all that management has become more reluctant to share information with union during JLMC meetings in the 1990s. Rather, he feels that management is actually more willing to share confidential information with union. Management does believe that union-side members of JLMC are a good mechanism to disseminate information to the rank and files.

Our union interviewee believes that general employee interest in JLMCs has risen in the 1990s. He receives more feedback (personal letters to him concerning his proceedings of JLMC meetings that are distributed to all union members) lately. He even receives requests from plant-level managers to send the proceedings to them. More importantly, our union interviewee feels an increasing desire of employees for union to help management making good decision during JLMCs.

For the last five years, the firm has been using a PSP. An additional bonus of up to 0.4 months of monthly regular wage will be given to all employees when a pre-specified performance indicator reaches a 
certain pre-determined target. This PSP bonus is not distributed equally to all employees. On average 20 percent of employees do not receive any PSP bonus, based on subjective performance evaluation of all employees. This is a combination of a collective incentive pay scheme and an individual incentive pay scheme, and can be considered a mechanism to ease the free-rider problem of PSPs. Performance indicator has changed from current profit to sales profit. Targets have been set every year by JLMC. However, due to poor performance of the firm in the last five years, the target was rarely reached.

\section{d. Firm D}

Firm D is a large manufacturing firm with sales of a few trillions of yen (about one third of which is export sales) and employment of close to 40,000 workers in 1998. It is listed in the first section of Tokyo Stock Exchange. Unlike the first three firms, Firm D's sales and employment did not fall dramatically in the 1990s although its share price did fall as drastically as the other firms in the same time period. Our case study of this firm generally adds little to what we have already reported above except that the firm has long subscribed to the complementarity in time model, i.e., all items will be discussed first at HQ-JLMCs and collective bargaining will be used only when HQ-JLMCs cannot resolve differences between management and labor. We report this case mostly because of unusually rich data on their ESOP that we were able to acquire from the firm. The data suggest subtle yet potentially important changes in the scope and nature of their ESOP.

Firm D introduced its ESOP in 1971. Like in the case of Firm A, the initial objective of the ESOP was threefold: (i) enhancing the sense of participation and motivating employees; (ii) providing a source of retirement income; and (iii) acquiring a stable shareholder group. By the end of 1980, the ESOP participation rate reached one in four employees and their average monthly contribution reached 13,000 in 1995 yen. As shown in Figure 20, since 1990, the participation rate has fallen to almost one in five employees. The average monthly contribution also decreased in early 1990 s to below 12,000 , and a subsequent recovery has not been strong.

The falling participation in ESOP is accounted for by a decrease in new participants and an 
increase in exiting participants. Figures 21 and 22 show the number of new participants and their average monthly contribution and the number of exiting participants and their average monthly contribution respectively. The number of new participants has fallen from nearly 1,000 a year in 1990 to a little over 200 a year in 1998 except for 1994 when there was a one-time jump. On the other hand, the number of exiting participants has doubled from 400 in 1990 to 800 in 1998. It follows that in 1998, there was a net loss of 600 participants. Unfortunately, the data do not allow us to find out how many of these exiting participants were exiting from the trust while remaining in the firm and thus were "voluntarily leaving the ESOP trust." However, according to our primary interviewee in personnel, nearly all exiting participants were also exiting from the firm. It appears that there have been very few frenzied voluntary exits from the trust. It appears that the ESOP is proving to be a stable shareholder here.

The direct cost of running the ESOP for the firm (consisting of subsidies to participants and administrative costs) is extremely small relative to the total labor cost. As shown in Figure 23, the direct cost is mostly the subsidies and it has been decreasing with the falling number of participants. In 1998, the total direct cost of running the ESOP is only a fraction of the total labor cost ( 0.08 percent).

ESOP participants, though remaining in the trust, fine-tuned their commitments to the trust by changing their monthly contributions. As shown in Figure 24, during 1990, more than 1,000 continuing participants increased their monthly contributions whereas only 100 continuing participants reduced their monthly contributions. In early 1990 s, fewer and fewer continuing participants were increasing their monthly contributions and more and more continuing participants were reducing their monthly contributions. By 1993, the number of continuing participants reducing their monthly contributions became nearly identical to the number of continuing participants increasing their monthly contributions. Since then, the number of continuing participants increasing their contributions has stopped falling whereas the number of continuing participants reducing their contributions has declined somewhat. As a result, during 1998 there were still more continuing participants who increased their contributions than those who reduced them. However, the difference between the two (about 100) was much smaller than it used to be in early 1990s (e.g., more than 900 in 1990). In short, though most ESOP participants remain in 
the trust unless they separate from the firm, fewer participants increase their contributions to the trust and more reduce their contributions. The overall commitment of ESOP participants to the trust appear to be falling somewhat as a result of worsening stock performance of the company.

\section{e. CONCLUDING REMARKS FROM FIELD RESEARCH}

\section{Timely and cost-effective management}

Critics of participatory management, in particular JLMCs and SFCs, argue that participatory management is too time-consuming and that it cannot adjust effectively to a rapidly changing competitive environment. In addition, it consumes too much effort of management, union and general employees which could be used for more productive activities. Both management and union of our large listed firms argue that JLMCs rarely delay important management decision, and stress the benefit of having a thoroughly convinced and ready labor force as a result of good JLMCs. When management decision is actually implemented, there will be no surprise, no misunderstanding, and no confusion among employees, which will make the process of implementation smooth and fast. Our personnel interviewee of Firm A, however, recognizes that the firm did experience a major delay in its decision to open a plant overseas due to union's strong objection in 1985 and that the current system was build on the premise that the same problem should not be repeated. He further adds that restructuring meetings and individual item meetings can be held immediately when either management or labor requests. The increased use of these meetings as opposed to more regular meetings such as management council meetings can be viewed as a mechanism to achieve timely management within the existing framework of JLMCs.

In contract, top management of our medium-size unlisted firm appears to be currently subscribing somewhat to the critics of participatory employment practices by proposing to reduce the frequency of JLMC meetings and shorten the length of each meeting from four to two hours.

\section{Pre-negotiation and threat effects}


Neither management nor union in all cases views JLMCs as a joint-decision making mechanism through which management and labor decide jointly on basic business strategies. However, both recognize that decisions made by management rarely turn out to be considered "unreasonable" by employees. First, management and union representatives, in particular top three union officials, tend to engage in extensive informal pre-negotiation prior to formal JLMCs meetings. As a result, management proposals that are submitted to JLMCs have already been revised to incorporate input from union. Second, when management works out its business strategies, it is fully aware of what will be viewed as "unreasonable" by employees and thus tends to avoid proposing "unreasonable" plans due to their fear of destroying its good working relationship with its union, or wasting time and effort by lengthy and costly negotiation with union.

\section{Complementarity of Employment Practices $^{12}$}

We asked both our union interviewees and personnel manager interviewees the following question.

Suppose it is necessary to streamline and downsize a set of participatory employment practices consisting of JLMCs (at the headquarters level and at the establishment level), SFCs, SGAs, ESOPs and PSPs. Would it be possible to eliminate one of those employment practices? If so, which one? General response to this question is "it would not be possible to take out any of the following three: JLMCs at the headquarters level, JLMCs at the establishment level and SFCs since they actually work hand in hand." However, when pressed to choose one of those three to eliminate, our union interviewee of Firm A mentioned that he would choose SFCs since in the past industrial relations did work fine without it. Our personnel interviewee's response turned out to be almost identical. However, he added that SFCs were not really costly (they were held outside of regular hours) and that their positive morale effects would be rather

\footnotetext{
${ }^{12}$ For complementarity of various employment practices, see, for instance, Fitzroy and Kraft (1987); Weitzman and Kruse (1990); Levine and Tyson (1990); Jones and Pliskin (1991); Ben-Ner and Jones (1995); Kandel and Lazear (1992); Kruse (1993); Holmstrom and Milgrom (1994); Baker, Gibbons and Murphy (1994); Milgrom and Roberts (1995); Ichniowski, Shaw and Prennushi (1997), Black and Lynch (1997), Helper (1998) and articles featured in a special issue of Industrial Relations (Vol. 35, July 1996).
} 
substantial. In other words, according to him, SFCs are probably a most cost-effective participatory practice. In addition, he anticipates in the future that as decentralization of the firm progresses, naturally the importance of JLMCs at the headquarters level will diminishes and the importance of establishment level-JLMCs and SFCs will increase.

Our field research also revealed that there are two kinds of complementary relations between collective bargaining and JLMCs; (i) complementarity in scope; and (ii) complementarity in time. According to the complementarity in scope model, collective bargaining deals with wages, bonuses, working hours and agreement revision whereas JLMCs deal with all other items. Thus, depending on an item to be discussed, either JLMCs or collective bargaining will be used. According to the complementarity in time model, all items will be discussed first at JLMCs and collective bargaining will be used only when JLMCs cannot resolve differences between management and labor. The majority of our firms subscribe to the complementarity in scope model. No firm suggested that they are substitutes.

\section{$\underline{4 .}$ Gap between full-time union officials and the rank and files}

For JLMCs to work well, management needs to prove credibly that they trust union representatives by providing them with confidential information. Based on our observations of top union officials, it seems to be almost impossible to continue to deceive them by providing them with superficial information while claiming it as "confidential". It appears to be the case that top management does provide top union officials with truly confidential information. By the very nature of confidential information, top management cannot allow such information to go beyond top union officials since it will be prohibitively costly to monitor information flow of all employees. Thus, management asks top union officials to keep such information among themselves. A problem with this solution is that it produces a gap between top union officials and the rank and files. When the rank and files find out some important business decisions such as alliance with another firm from newspapers and TV instead of hearing from their management, they will be naturally upset about the fact that their management releases such important information to 
media before releasing it to its own employees. When that happens, they will ask their union officials whether they knew. When union officials deny it, sooner or later, the rank and files will start considering their own union officials either as incompetent or even worse as working for management not for them. Eventually, a good, cooperative relationship between labor and management will turn into a complicated, not always cooperative three way relationship among the rank and files, union officials and top management. We are not suggesting this is actually happening in our four firms. We are pointing out a possible cause of the breakdown of the system of participatory employment practices.

\section{$\underline{\text { 5. Overloading labor representatives and limited supply of full-time union officials }}$}

Many firms have been downsizing. For example, as shown in Figure 12, Firm A has reduced its labor force by more than 30 percent in the 1990s. To keep pace with this downsizing, the number of full-time union officials in Firm A has also fallen in 1990s. However, as shown in Figure 14, activities of JLMCs have not diminished accordingly. Rather they have intensified recently. This is making full-time union officials exceedingly busy while there is no sufficient monetary compensation for this increased work load. For example, our secondary union interviewees at Firm A complain that the amount of work they are asked to do has increased substantially recently. They appear to be looking forward to returning to some management positions within the firm after their current union posts.

If this trend of overloading of labor representatives continues in the future, the system of participatory employment practices may break down. First, labor representatives may not be as wellprepared for JLMC meetings as before since they are simply too busy with the increased work load. Second, the increased work load with no monetary compensation for it makes union posts somewhat less attractive to young, capable employees which are increasingly becoming scarce as a result of the aging of the labor force in general. In addition, substantially diminished employment opportunities outside of the firm may make full-time union officials more dependent on the firm for their future employment after finishing their union posts. Furthermore, as a result of downsizing, managers may become more reluctant 
to sending their best people from their organizations to union posts. All these things may make labor representatives for JLMCs less prepared, less committed to the interest of the rank and files, and less effective. Without well-prepared, firmly-committed, and effective labor representatives, JLMCs will become a mere formality. A real danger to the survival of participatory employment practices might come not from management but from unions. If participatory employment practices disappear from Japanese firms in the future, it might be due not to management initiatives but to the lack of capable and committed labor representatives.

\section{$\underline{\text { IV. Conclusions }}$}

In this paper we have shown that participatory employment practices appear to be surviving in general in the economic slowdown in the 1990 s whereas subtle yet potentially important changes in their attributes are taking place.

Kato and Morishima (1999) provide econometric evidence for the complementarity of these participatory employment practices. Terminating a single practice may not only eliminate its own positive effect but reduce the positive effects of other practices. In the extreme case, the termination of a single practice may cause the whole system of employee participation and labor-management cooperation to halt.

For example, it was found that the goal alignment process needed to be supported both by direct methods (financial participation) and indirect ones (information sharing). Removing financial participation will cause information sharing to be ineffective and vice versa. Furthermore, it was found necessary for information sharing to take place not only at the top level but at the grass roots level. Discontinuing information sharing at the grass roots level will cause information sharing at the top level to be ineffective, and vice versa.

Moreover, research points to the importance of a long-term perspective in evaluating the success of participatory employment practices. ${ }^{13}$ Coupled with the importance of the long-term perspective, the complementarity of participatory employment practices will probably make individual Japanese 
employment practices more enduring than the popular rhetoric of "the end of Japanese employment practices" suggests. Our findings on the responses of Japanese firms in their use of participatory employment practices to the economic slowdown in the 1990s do point to the enduring nature of such practices for large unionized firms. Such Japanese firms appear to be responding to the economic slowdown in the 1990s and the recent financial crisis in particular by fine-tuning the existing practices not by dismantling them. For small to medium size firms with no union, we find some evidence for management to try to weaken the role of employee participation. Combined with rising proportion of the non-union sector in the Japanese economy, the overall importance of participation in the Japanese economy may be falling.

There are a few early signs of trouble even for large, unionized firms which might eventually result in the breakdown of the system if left untreated. First, the number of full time union officials has been falling as a result of continued downsizing of the firm's labor force. The amount of time and effort that union officials need to put into participatory employment practices have not been falling. This often results in an uncompensated increase in work load for union officials. If this trend continues, union officials who have been playing a key role in Japanese participatory management will become less effective and less committed to the interest of the rank and files. Second, at least in our medium-size firm case, top management is finding its participatory management system detrimental to timely and efficient management, and has begun to streamline the system. Overloaded union officials may offer less resistance to such management initiatives. Third, the current system tends to produce a gap in the quantity and quality of information acquired from management between top union officials and their general membership. It is conceivable that such a gap may eventually result in the breakdown of the system. These are still preliminary observations. Clearly more work is necessary to make more definitive answers to these important questions.

\footnotetext{
${ }^{13}$ See, for instance, Kato and Morishima (1999).
} 


\section{REFERENCES}

Baker, George, Gibbons, Robert, and Murphy, Kevin J. "Subjective Performance Measures in Optimal Incentive Contracts,” Quarterly Journal of Economics, November 1994, 108 (8), pp. 1125-56.

Bartel, Ann P. "Human Resource Management and Performance in the Service Sector: The Case of Bank Branches," NBER Working Paper No. 7467, January 2000.

Ben-Ner, Avner, and Jones, Derek C. "Employee Participation, Ownership, and Productivity: A Theoretical Framework," Industrial Relations, October 1995, 34 (4), pp. 532-54.

Black, Sandra E. and Lynch, Lisa M. "How to Compete: The Impact of Workplace Practices and Information Technology on Productivity,” NBER Working Paper No. 6120, August 1997.

Brunello, Giorgio. "Bonuses, Wages and Performances in Japan: Evidence from Micro Data." Ricerche Economiche, April-September 1991, 45 (2-3), pp. 377-396.

Cole, Robert E. Strategies for Learning: Small-Group Activities in American, Japanese, and Swedish Industry. Berkeley, CA: University of California Press, 1989.

Fitzroy, Felix R. and Kraft, Kornelius. "Cooperation, Productivity and Profit Sharing." Quarterly Journal of Economics, February 1987, 102 (1), pp. 23-35.

Freeman, Richard B. and Kleiner, Morris M. "From Piece Rates to Time Rates: Surviving Global Competition," Paper presented at the Industrial Relations Research Association Meetings in Chicago, January 1998.

Freeman, Richard B., Kleiner, Morris M., and Ostroff, Cheri. "The Anatomy and Effects of Employee Involvement." Paper presented at the American Economic Association Meetings in New Orleans, January 1997.

Freeman, Richard B. and Weitzman, Martin L. "Bonuses and Employment in Japan." Journal of the Japanese and International Economies, June 1987, 1 (2), pp. 168-194.

Hart, Robert A. and Kawasaki, Seiichi. "The Japanese Bonus System and Human Capital.” Journal of the Japanese and International Economies, September 1995, $\underline{9}$ (3), pp. 225-44.

Hashimoto, Masanori. The Japanese Labor Market in a Comparative Perspective with the United States. Kalamazoo, Michigan: Upjohn Institute for Employment Research, 1990.

Helper, Susan. “Complementarity and Cost Reduction: Evidence from the Auto Supply Industry,” Revised version of NBER working paper \#6033, April 1998

Holmstrom, Bengt and Milgrom, Paul. "The Firm as an Incentive System," American Economic Review, September 1994, 84 (4), pp. 972-91.

Ichniowski, Casey and Shaw, Kathryn. "Old Dogs and New Tricks: Determinants of the Adoption of Productivity-Enhancing Work Practices," Brookings Papers on Economic Activity, Microeconomics 1995, pp. 1-55. 
Ichniowski, Casey, Shaw, Kathryn, and Giovanna Prennushi. "The Effects of Human Resource Management Practices on Productivity: A Study of Steel Finishing Lines." American Economic

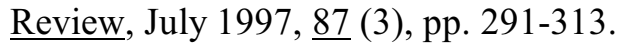

Inagami, Takeshi. Japanese Workplace Industrial Relations Industrial Relations Series, No. 14. Tokyo: The Japan Institute of Labour, 1988.

Japan Productivity Center. To Improve Joint Labor Management Committees (Roshikyogisei no Jujitsu o Motomete), Tokyo: Japan Productivity Center, 1990.

Jones, Derek., and Kato, Takao. "The Productivity Effects of Employee Stock Ownership Plans and Bonuses: Evidence from Japanese Panel Data." American Economic Review, June 1995, $\underline{85}$ (3), pp. 391-414.

Jones, Derek C., and Pliskin, Jeffrey. "The Effects of Worker Participation, Employee Ownership and Profit Sharing on Economic Performance: A Partial Review," in Russell, Raymond, and Rus, Veljko, eds., Ownership and Participation: International Handbook of Participation in Organizations, Vol.2. Oxford: Oxford University Press, 1991, pp. 43-63.

Kandel , Eugene and Lazear, Edward. "Peer Pressure and Partnerships,” Journal of Political Economy, August 1992, 100 (4), pp. 801-17.

Kang, Jun-Koo and Stulz, Rene M. "Is Bank-centered Corporate Governance Worth It? A Cross-sectional Analysis of the Performance of Japanese Firms During the Asset Price Deflation," Paper presented at the NBER Japan Project Meeting, Cambridge, MA., April 18, 1998

Kato, Takao. "COOPERATE TO COMPETE Employee Participation and Productivity: Evidence from a New Survey of Japanese Firms," Public Policy Brief (The Jerome Levy Economics Institute, Bard College), No. 19, 1995.

Kato, Takao and Morishima, Motohiro. "The Productivity Effects of Participatory Employment Practices: Evidence From New Japanese Panel Data," Mimeo, Department of Economics, Colgate University, May 1999.

Koike, Kazuo. Worker Participation (Rodosha no Keiei Sanka), Tokyo: Nihon Hyoron Sha, 1978.

Kruse, Douglas L. Profit Sharing: Does It Make a Difference? Kalamazoo, Michigan: W.E. Upjohn Institute for Employment Research, 1993.

Levine, David I. Reinventing the Workplace, Washington, D.C.: Brookings Institution, 1995.

Levine, David I. and Tyson, Laura D'Andrea. "Participation, Productivity and the Firm's Environment," in Blinder, Alan S., ed., Paying For Productivity, Washington, D.C.: Brookings Institution, 1990, pp. 183-236.

Milgrom, Paul and Roberts, John. "Complementarities and Fit: Strategy, Structure, and Organizational Change in Manufacturing," Journal of Accounting and Economics, April 1995, 19 (2-3), pp. 179208.

Morishima, Motohiro. "Information Sharing and Firm Performance in Japan: Do Joint Consultation Committees Help?" Industrial Relations, Winter 1991a, 30 (1), pp. 37-61. 
Morishima, Motohiro. "Information Sharing and Collective Bargaining in Japan: Effects on Wage Negotiations." Industrial and Labor Relations Review, April 1991b, 44 (3), pp. 469-485.

Nakamura, Masao and Nakamura, Alice. "Risk Behavior and the Determinants of Bonus Versus Regular Pay in Japan." Journal of the Japanese and International Economies, September 1989, $\underline{3}$ (3), pp. 270-291.

Ohashi, Isao. "On the Determinants of Bonuses and Basic Wages in Large Japanese Firms." Journal of the Japanese and International Economies, December 1989, $\underline{3}$ (4), pp. 451-479.

Ohkusa, Yasushi and Ohtake, Fumio. "The Productivity Effects of Information Sharing, Profit-Sharing and ESOPs," Journal of the Japanese and International Economies, September 1997, 11(3), pp. 385402.

Pil, Frits K., and MacDuffie, John Paul. “The Adoption of High-Involvement Work Practices.” Industrial Relations, July 1996, 35 (3), pp. 423-455.

Shimada, Haruo. "Japan's Industrial Culture and Labor-Management Relations." In Shumpei Kumon and Henry Rosovsky, eds., The Political Economy of Japan, Volume 3: Cultural and Social Dynamics. Stanford: Stanford University Press, 1992, pp. 267-291.

Tsuru, Tsuyoshi and Morishima, Motohiro. "Nonunion Employee Representation in Japan.” Journal of Labor Research, Winter 1999, 20 (1), pp. 93-110.

Weitzman, Martin, L. and Kruse, Douglas L. "Profit Sharing and Productivity," in Blinder, Alan, ed., Paying For Productivity, Washington, D.C.:Brookings Institution, 1990, pp.95-140. 
Table 1 Temporary and Permanent Transfers from 1995 to 1998: Firm A

\begin{tabular}{|c|c|c|c|c|c|c|c|c|c|c|c|c|c|}
\hline & & $95 / 1$ & $95 / 2$ & 95 & $96 / 1$ & $96 / 2$ & 96 & $97 / 1$ & $97 / 2$ & 97 & $98 / 1$ & $98 / 2$ & 98 \\
\hline \multirow[t]{4}{*}{ temporary transfer } & related firms & 478 & 325 & 803 & 369 & 82 & 451 & 334 & 107 & 441 & 182 & 104 & 286 \\
\hline & sales firms & 1131 & 417 & 1548 & 1174 & 175 & 1349 & 537 & 218 & 755 & 617 & 62 & 679 \\
\hline & other firms & 159 & 112 & 271 & 101 & 45 & 146 & 57 & 25 & 82 & 33 & 26 & 59 \\
\hline & Total & 1768 & 854 & 2622 & 1644 & 302 & 1946 & 928 & 350 & 1278 & 832 & 192 & 1024 \\
\hline \multirow[t]{4}{*}{ permanent transfer } & related firms & 297 & 11 & 308 & 235 & 73 & 308 & 197 & 7 & 204 & 206 & 3 & 209 \\
\hline & sales firms & 133 & 25 & 158 & 217 & 28 & 245 & 268 & 118 & 386 & 52 & 5 & 57 \\
\hline & other firms & 72 & 117 & 189 & 88 & 44 & 132 & 23 & 14 & 37 & 31 & 14 & 45 \\
\hline & total & 502 & 153 & 655 & 540 & 145 & 685 & 488 & 139 & 627 & 289 & 22 & 311 \\
\hline
\end{tabular}

Source: Internal Documents of Firm A 
Table 2 Number of SFC Meetings Per Month at Each Establishment from 9/1996-8/1998: Firm A

\begin{tabular}{r|rrrrrrrrrrrr}
\hline & est.1 & est.2 & est.3 & est.4 & est.5 & est.6 & est.7 & est.8 & est.9 & est.10 & est.11 & total \\
\hline Sep-96 & 3 & 16 & 3 & 18 & 9 & 4 & 20 & 12 & 1 & 4 & 12 & 102 \\
Oct-96 & 3 & 16 & 3 & 18 & 9 & 4 & 20 & 12 & 1 & 4 & 12 & 102 \\
Nov-96 & 45 & 11 & 1 & 16 & 11 & 7 & 21 & 4 & 2 & 3 & 7 & 128 \\
Dec-96 & 1 & 19 & 3 & 15 & 7 & 4 & 27 & 9 & 4 & 4 & 11 & 104 \\
Jan-97 & 12 & 14 & 0 & 13 & 8 & 5 & 15 & 12 & 12 & 5 & 3 & 99 \\
Feb-97 & 9 & 19 & 0 & 13 & 7 & 4 & 13 & 13 & 6 & 8 & 12 & 104 \\
Mar-97 & 1 & 10 & 2 & 7 & 11 & 1 & 16 & 7 & 4 & 8 & 2 & 69 \\
Apr-97 & 12 & 7 & 0 & 9 & 8 & 7 & 13 & 12 & 4 & 6 & 11 & 89 \\
May-97 & 4 & 14 & 1 & 9 & 8 & 3 & 14 & 10 & 4 & 12 & 10 & 89 \\
Jun-97 & 1 & 7 & 1 & 6 & 8 & 3 & 13 & 7 & 2 & 8 & 6 & 62 \\
Jul-97 & 5 & 9 & 0 & 2 & 4 & 0 & 10 & 8 & 0 & 3 & 8 & 49 \\
Aug-97 & 14 & 1 & 4 & 0 & 0 & 2 & 6 & 6 & 0 & 0 & 0 & 33 \\
total & 110 & 143 & 18 & 126 & 90 & 44 & 188 & 112 & 40 & 65 & 94 & 1030 \\
\# of shopfloors & 42 & 42 & 3 & 27 & 17 & 16 & 31 & 19 & 12 & 19 & 35 & 263 \\
annual average \# of meetings & 2.62 & 3.40 & 6.00 & 4.67 & 5.29 & 2.75 & 6.06 & 5.89 & 3.33 & 3.42 & 2.69 & 3.92 \\
Sep-97 & 11 & 20 & 4 & 10 & 3 & 3 & 12 & 8 & 0 & 15 & 35 & 121 \\
Oct-97 & 21 & 14 & 2 & 14 & 5 & 6 & 14 & 11 & 4 & 10 & 26 & 127 \\
Nov-97 & 5 & 17 & 1 & 11 & 4 & 2 & 13 & 9 & 6 & 12 & 19 & 99 \\
Dec-97 & 0 & 28 & 1 & 10 & 5 & 6 & 19 & 9 & 4 & 9 & 9 & 100 \\
Jan-98 & 79 & 29 & 1 & 9 & 9 & 6 & 14 & 6 & 8 & 14 & 21 & 196 \\
Feb-98 & 1 & 24 & 1 & 11 & 9 & 2 & 11 & 7 & 5 & 13 & 22 & 106 \\
Mar-98 & 0 & 18 & 1 & 6 & 7 & 1 & 11 & 6 & 2 & 10 & 69 & 131 \\
Apr-98 & 0 & 22 & 0 & 7 & 4 & 3 & 10 & 3 & 2 & 7 & 28 & 86 \\
May-98 & 0 & 17 & 2 & 3 & 4 & 1 & 13 & 9 & 2 & 6 & 37 & 94 \\
Jun-98 & 0 & 18 & 0 & 4 & 4 & 1 & 11 & 6 & 6 & 5 & 31 & 86 \\
Jul-98 & 2 & 20 & 0 & 1 & 4 & 4 & 10 & 3 & 6 & 8 & 36 & 94 \\
Aug-98 & 4 & 11 & 0 & 6 & 4 & 6 & 10 & 4 & 0 & 7 & 29 & 81 \\
total & 123 & 238 & 13 & 92 & 62 & 41 & 148 & 81 & 45 & 116 & 362 & 1321 \\
\# of shopfloors & 41 & 55 & 4 & 25 & 17 & 16 & 32 & 18 & 12 & 19 & 69 & 308 \\
annual average \# of meetings & 3.00 & 4.33 & 3.25 & 3.68 & 3.65 & 2.56 & 4.63 & 4.50 & 3.75 & 6.11 & 5.25 & 4.29 \\
\hline Source: Inters
\end{tabular}

Source: Internal Documents of Firm A 
Table 3 Changes in SGAs over time: Firm B

\begin{tabular}{|c|c|c|c|c|c|}
\hline year & $\#$ of groups & employee per group & $\begin{array}{r}\% \text { of blue-collar } \\
\text { employees } \\
\text { in SGAs }\end{array}$ & \# of projects & projects per group \\
\hline 92 & 3794 & 9.57 & $95.10 \%$ & 22238 & 5.86 \\
\hline 93 & 3545 & 9.77 & $95.40 \%$ & 22555 & 6.36 \\
\hline 94 & 3123 & 9.95 & $90.20 \%$ & 19042 & 6.10 \\
\hline 95 & 2874 & 9.60 & $95.70 \%$ & 17690 & 6.16 \\
\hline 96 & 2632 & 9.32 & $96.00 \%$ & 16004 & 6.08 \\
\hline 97 & 2447 & 9.22 & $95.40 \%$ & 15673 & 6.40 \\
\hline
\end{tabular}


FIGURE 1 ESOPs in Japan: 1979-1997

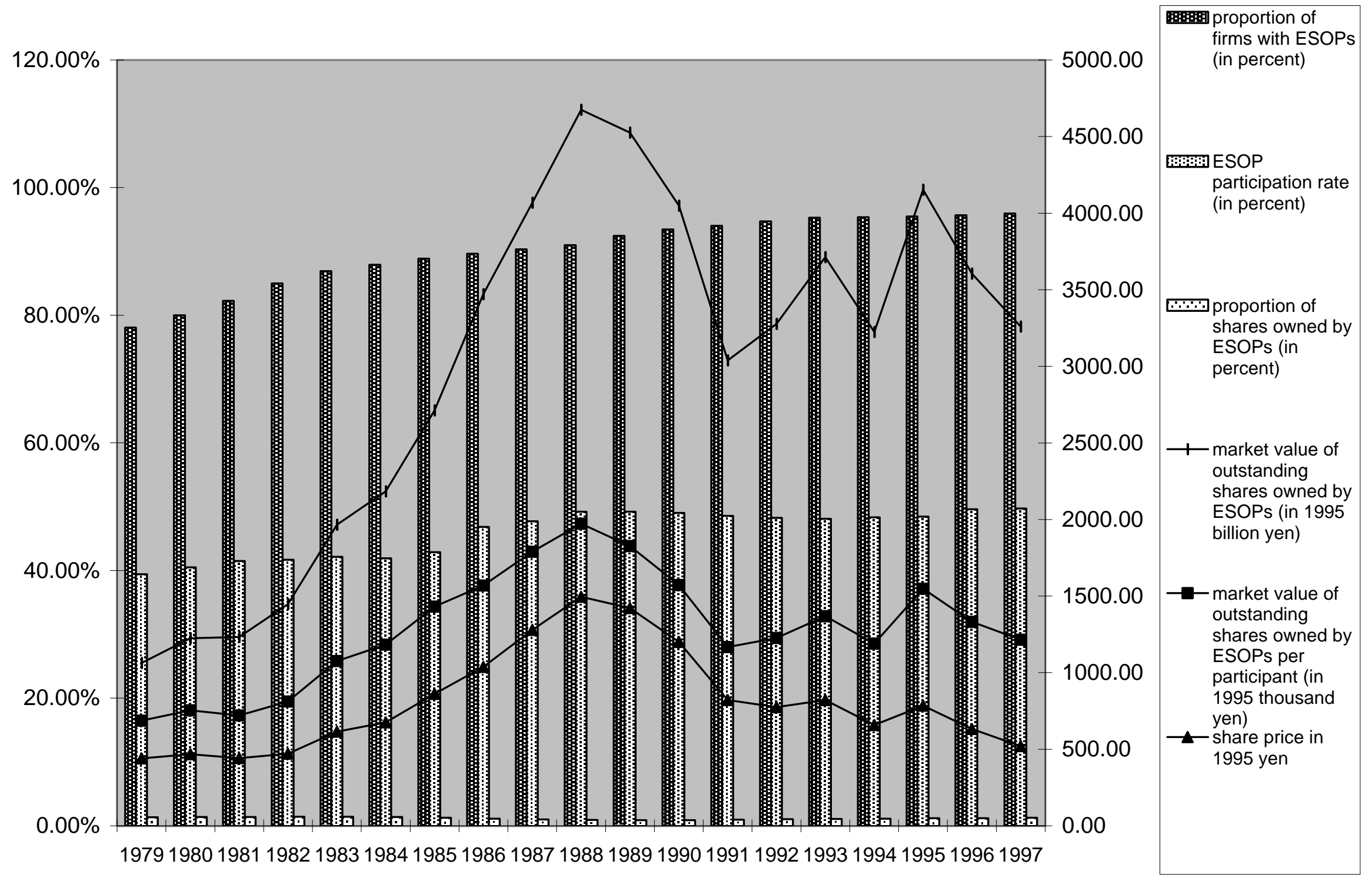




\section{FIGURE 2 Changes in Proportion of Firms with ESOPs from 1988-97 by Industries}

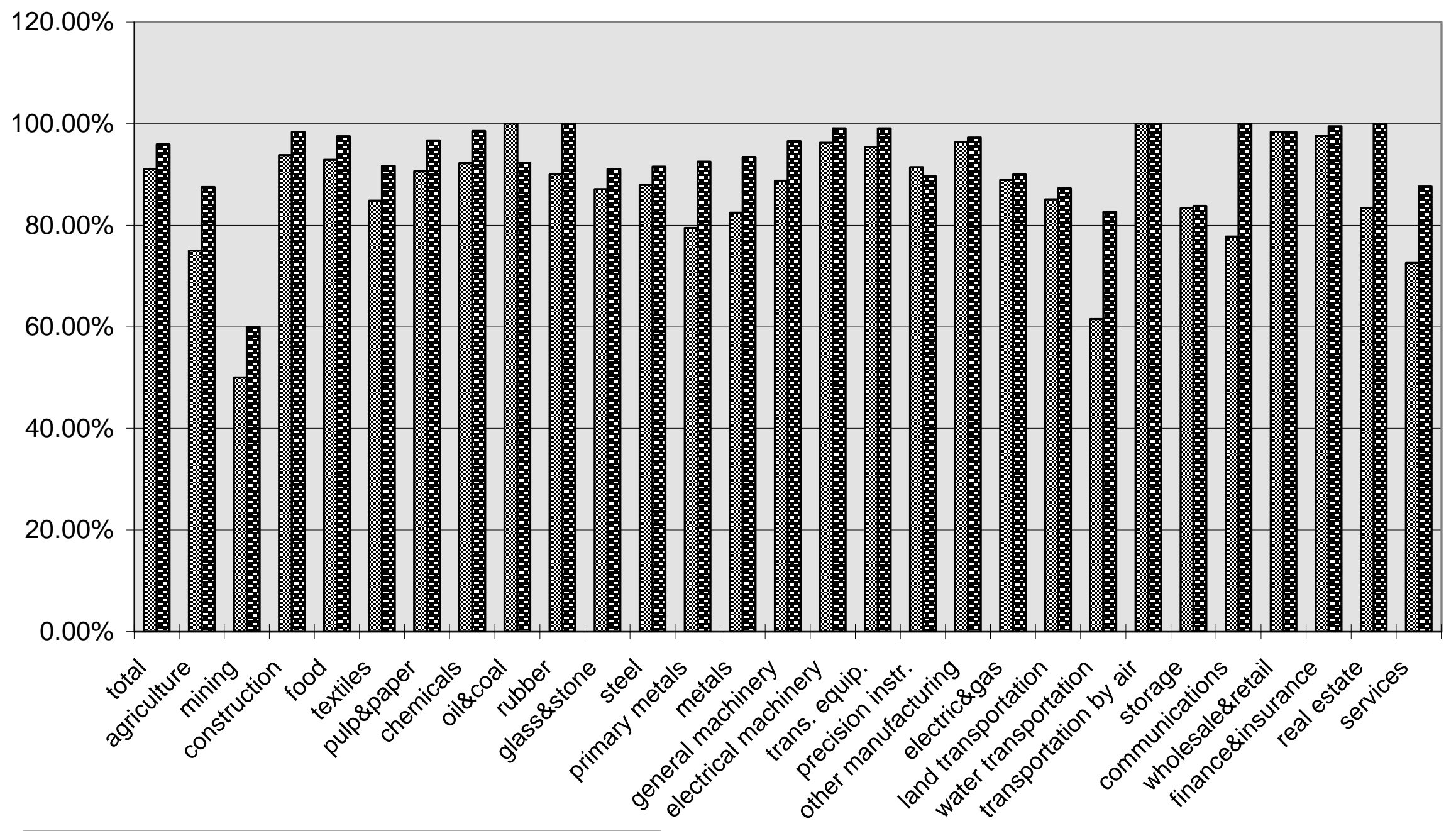

圆proportion of firms with ESOPs in 1988 (in percent)

Rproportion of firms with ESOPs in 1997 (in percent) 
FIGURE 3 Changes in ESOP Participation Rate from 1988-97 by Industries

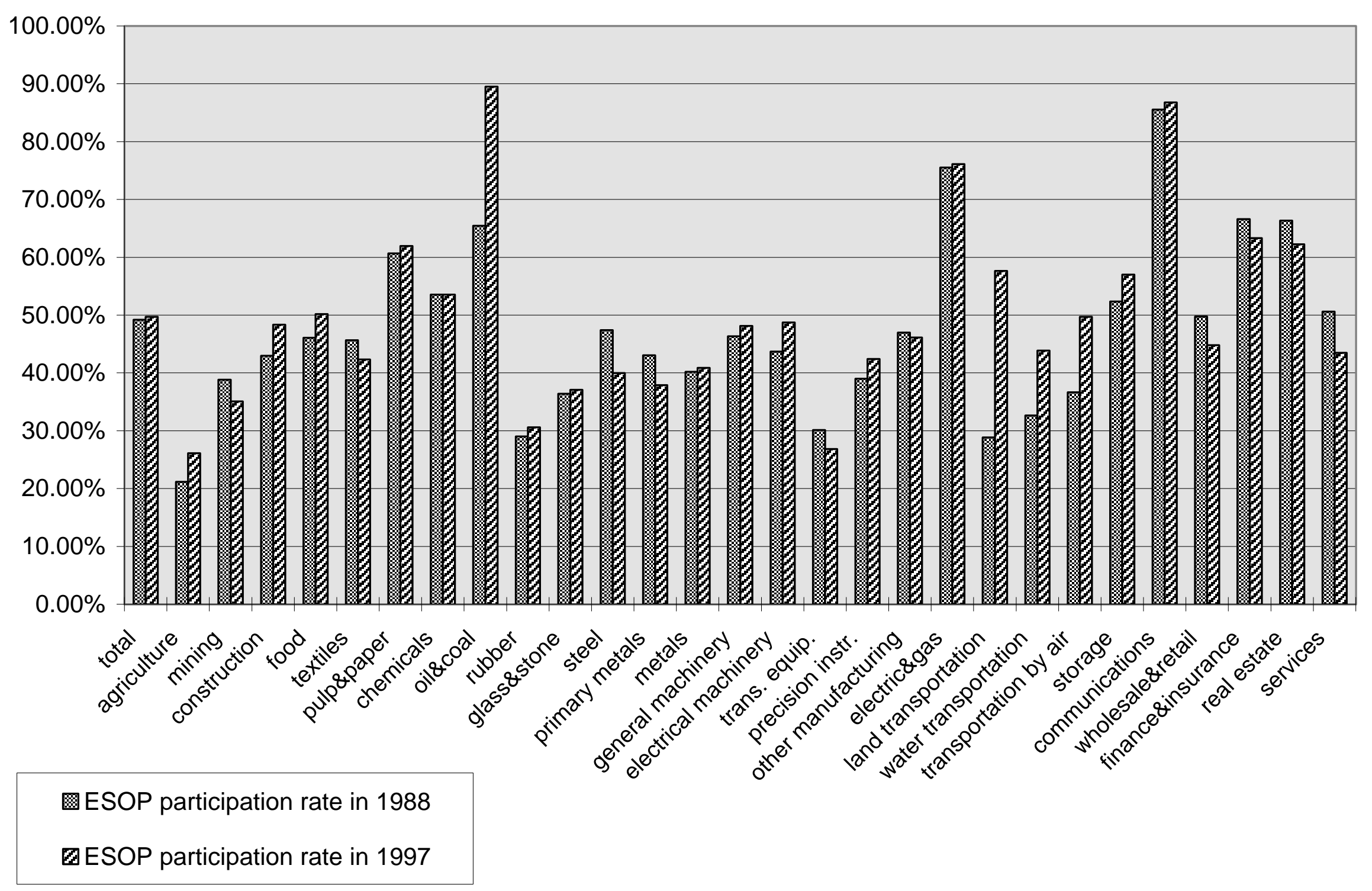


Figure 4 Proportion of Establishments with JLMCs in 1988 and 1995

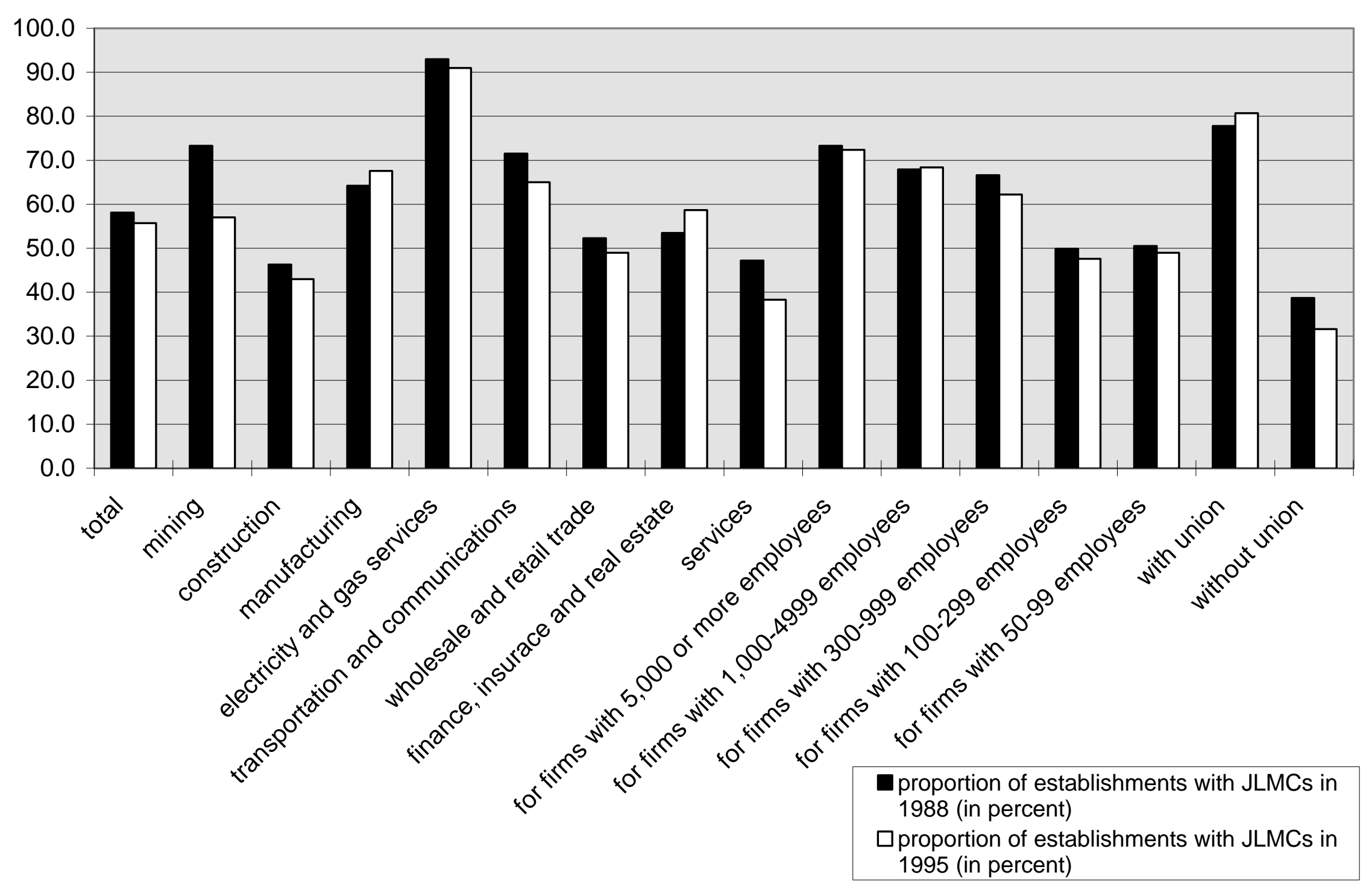


FIGURE 5 Average Number of JLMC Meetings per year in 1988 and 1995

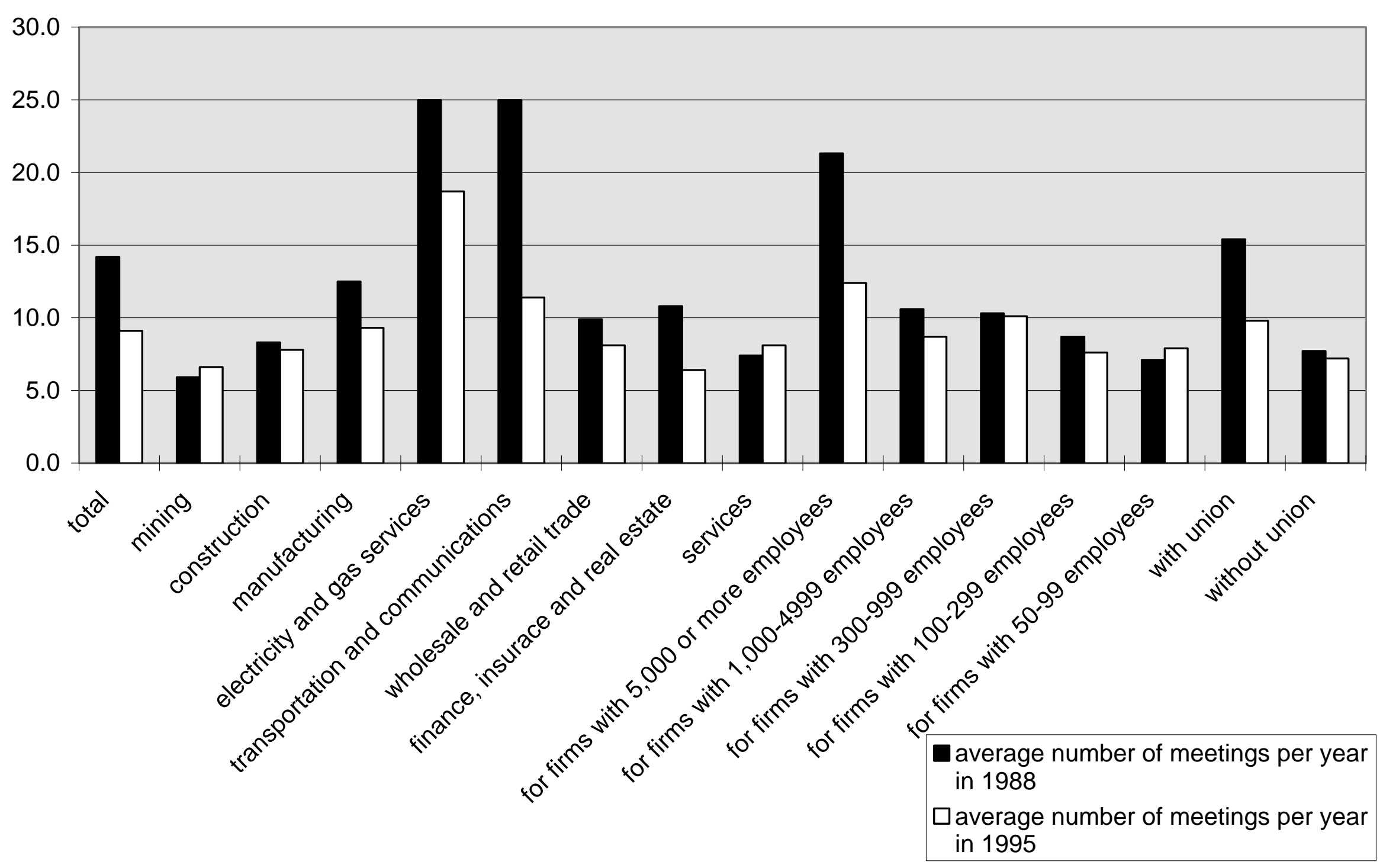


FIGURE 6 Average Number of Special Subcommittees in 1988 and 1995

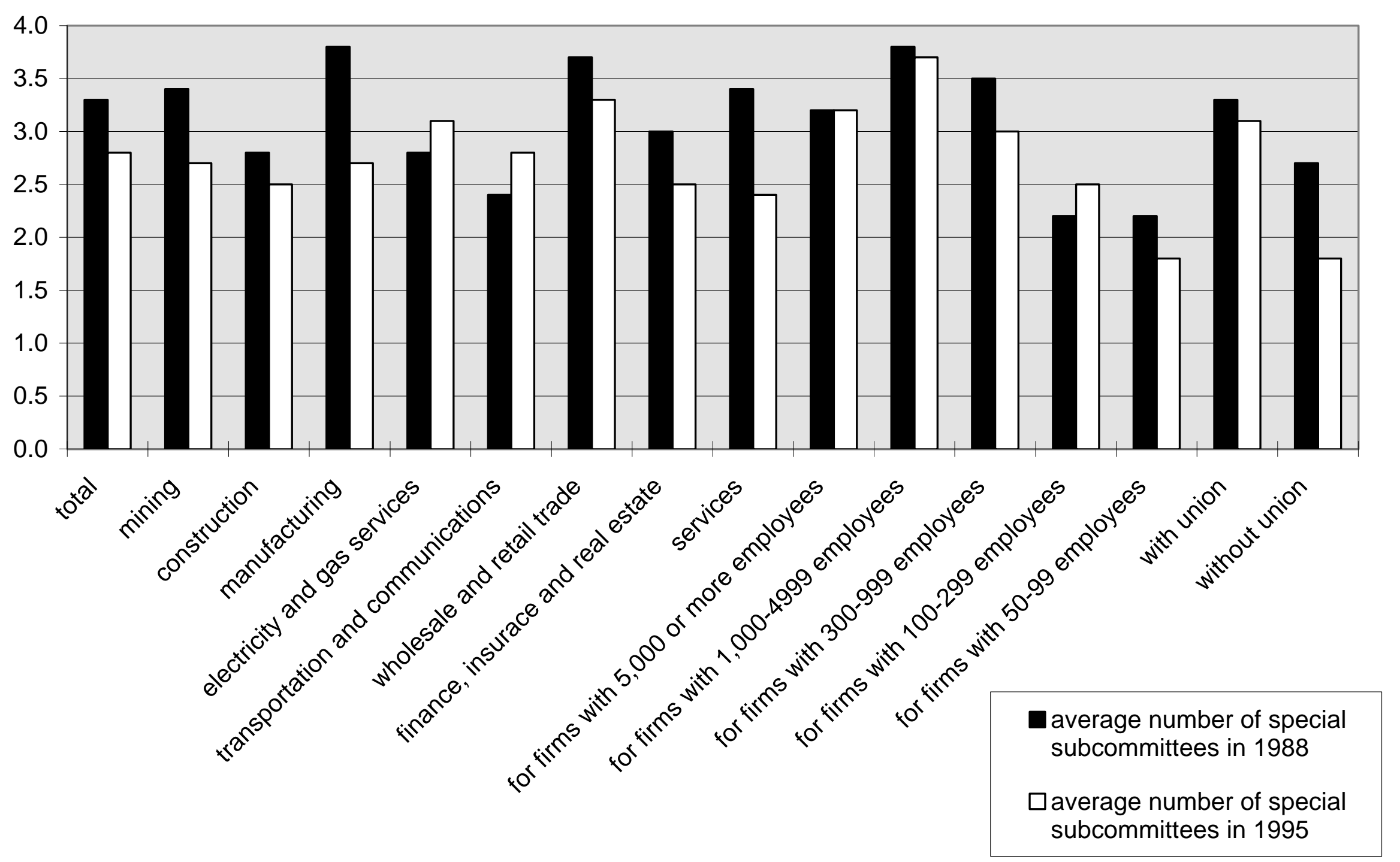




\section{FIGURE 7 Selection of Employee Representatives in Firms with and without Union in 1988 and 1995}

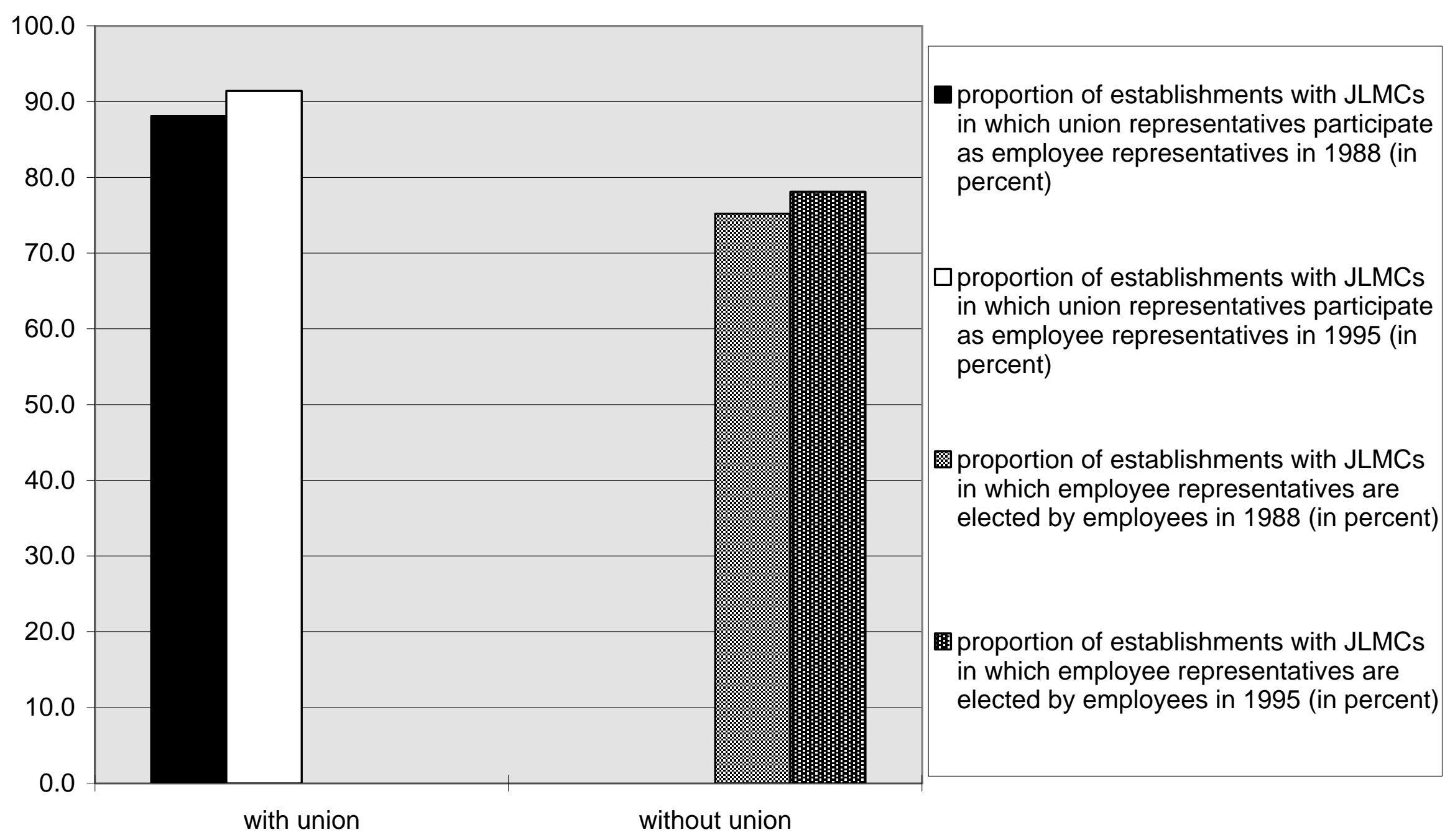




\section{FIGURE 8 Proportion of Unionized Establishments with JLMCs that Discuss Restructuring and Other Relevant Issues in 1988 and 1995}

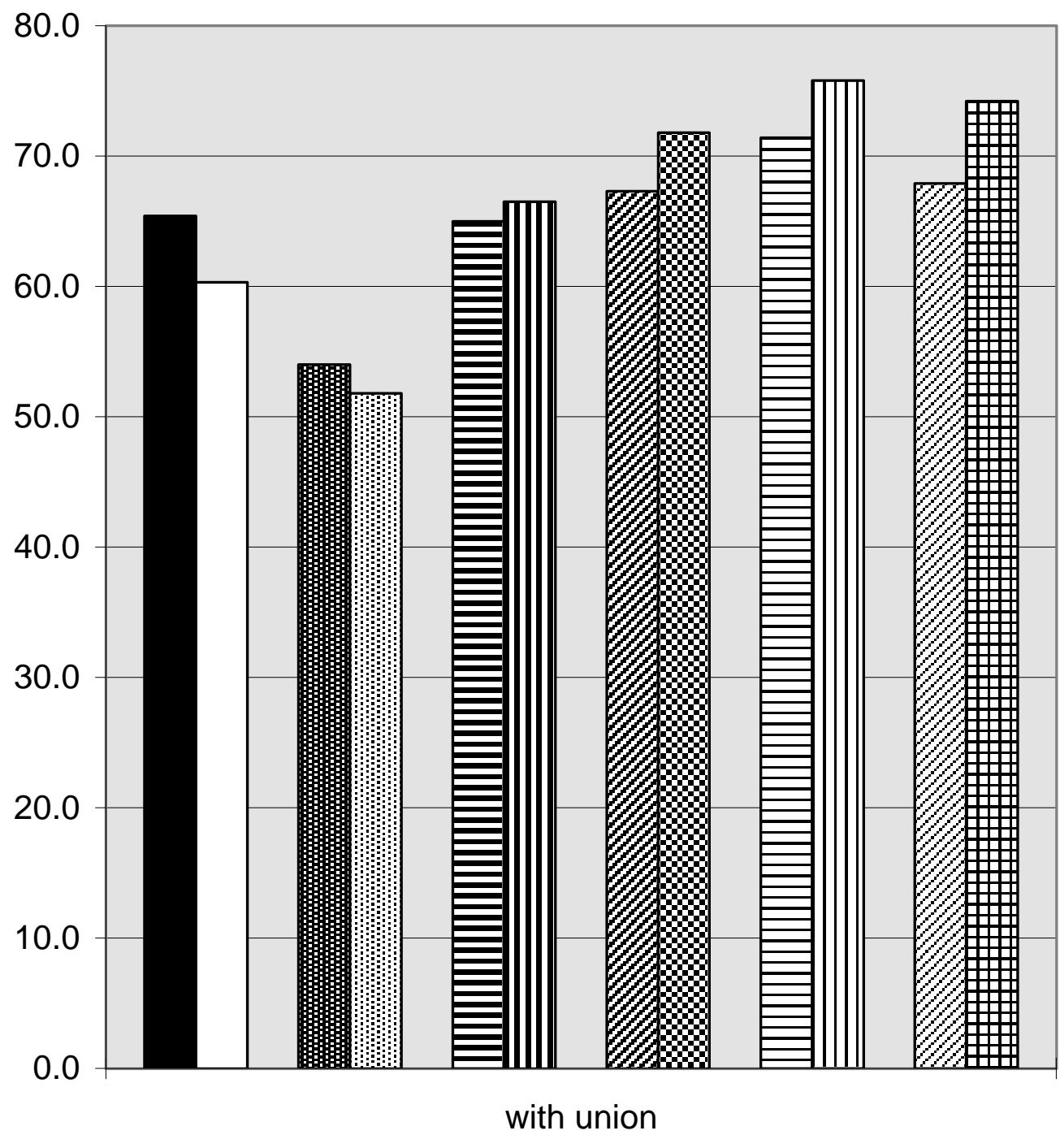

proportion of establishments with JLMCs that discuss corporate restructuring in 1988 (in percent)

$\square$ proportion of establishments with JLMCs that discuss corporate restructuring in 1995 (in percent)

\section{圆}

9: proportion of establishments with JLMCs that discuss hiring and staffing in 1988 (in percent)

国proportion of establishments with JLMCs that discuss hiring and staffing in 1995 (in percent)

G.

Eproportion of establishments with JLMCs that discuss transfer of employees in 1988 (in percent)

D proportion of establishments with JLMCs that discuss transfer of employees in 1995 (in percent)

$\mathbf{\nabla}$

$\triangle$ proportion of establishments with JLMCs that discuss layoff in 1988 (in percent)

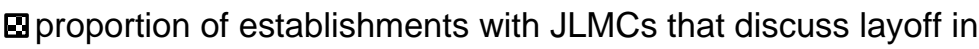
1995 (in percent)

因

日proportion of establishments with JLMCs that discuss mandatory retirement in 1988 (in percent)

$\square$ proportion of establishments with JLMCs that discuss mandatory retirement in 1995 (in percent)

\section{田}

$\approx$ proportion of establishments with JLMCs that discuss severance pay/pension in 1988 (in percent)

田proportion of establishments with JLMCs that discuss severance pay/pension in 1995 (in percent) 


\section{FIGURE 9 Proportion of Non-unionized Establishments with JLMCs that Discuss Restructuring and Other Relevant Issues in 1988 and 1995}

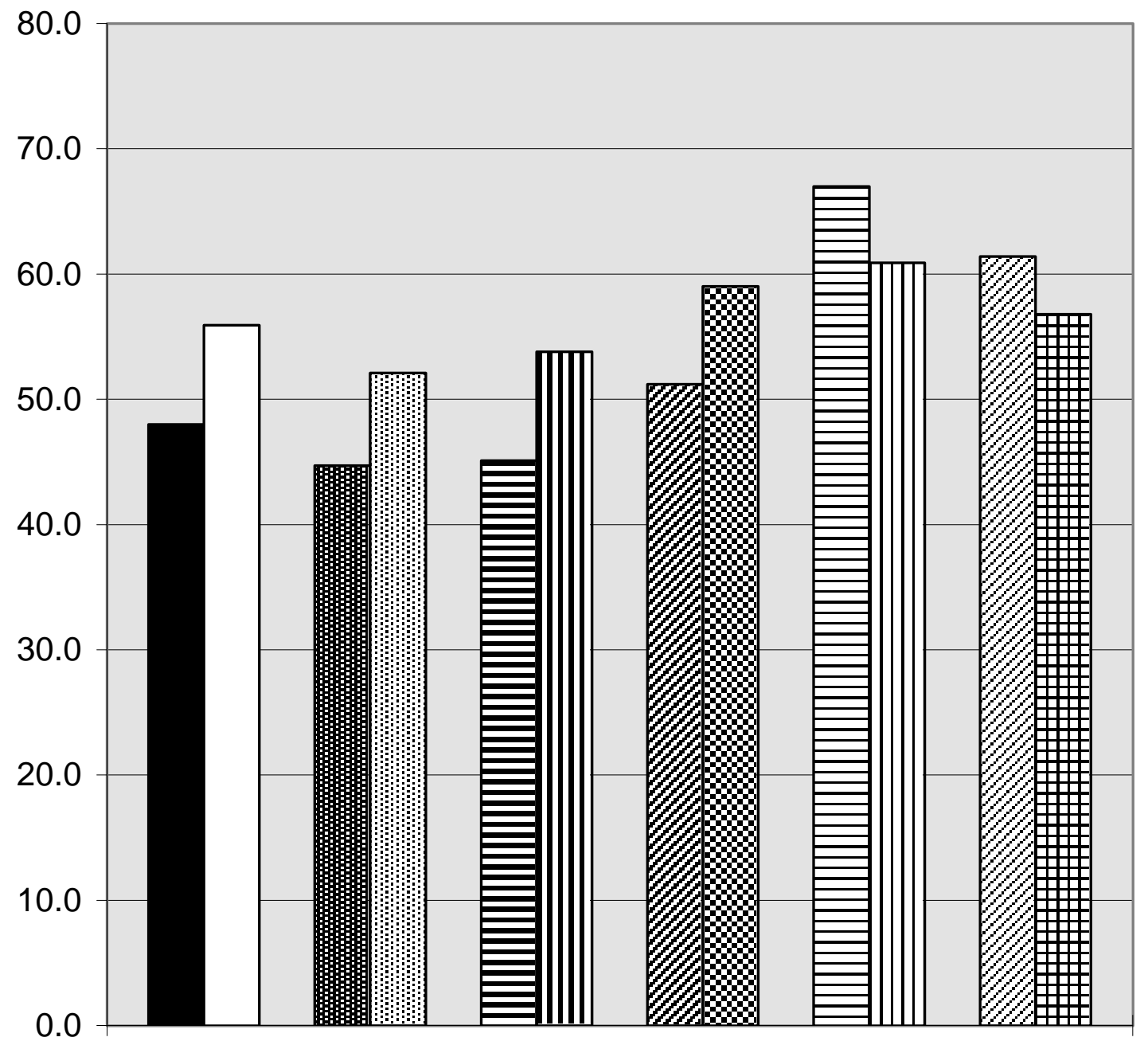

without union proportion of establishments with JLMCs that discuss corporate restructuring in 1988 (in percent)

$\square$ proportion of establishments with JLMCs that discuss corporate restructuring in 1995 (in percent)

圆

: proportion of establishments with JLMCs that discuss hiring and staffing in 1988 (in percent)

항 proportion of establishments with JLMCs that discuss hiring and staffing in 1995 (in percent)

๑

日proportion of establishments with JLMCs that discuss transfer of employees in 1988 (in percent)

口 proportion of establishments with JLMCs that discuss transfer of employees in 1995 (in percent)

$\mathbf{\nabla}$

$\square$ proportion of establishments with JLMCs that discuss layoff in 1988 (in percent)

Qproportion of establishments with JLMCs that discuss layoff in 1995 (in percent)

Eproportion of establishments with JLMCs that discuss mandatory retirement in 1988 (in percent)

$\square$ proportion of establishments with JLMCs that discuss mandatory retirement in 1995 (in percent)

囚

proportion of establishments with JLMCs that discuss severance pay/pension in 1988 (in percent)

田proportion of establishments with JLMCs that discuss severance pay/pension in 1995 (in percent) 


\section{FIGURE 10 Proportion of Unionized Establishments with JLMCs Discussing Restructuring and Other Relevant Issues that Ask Employee Representatives for Prior Consent in 1988 and 1995}

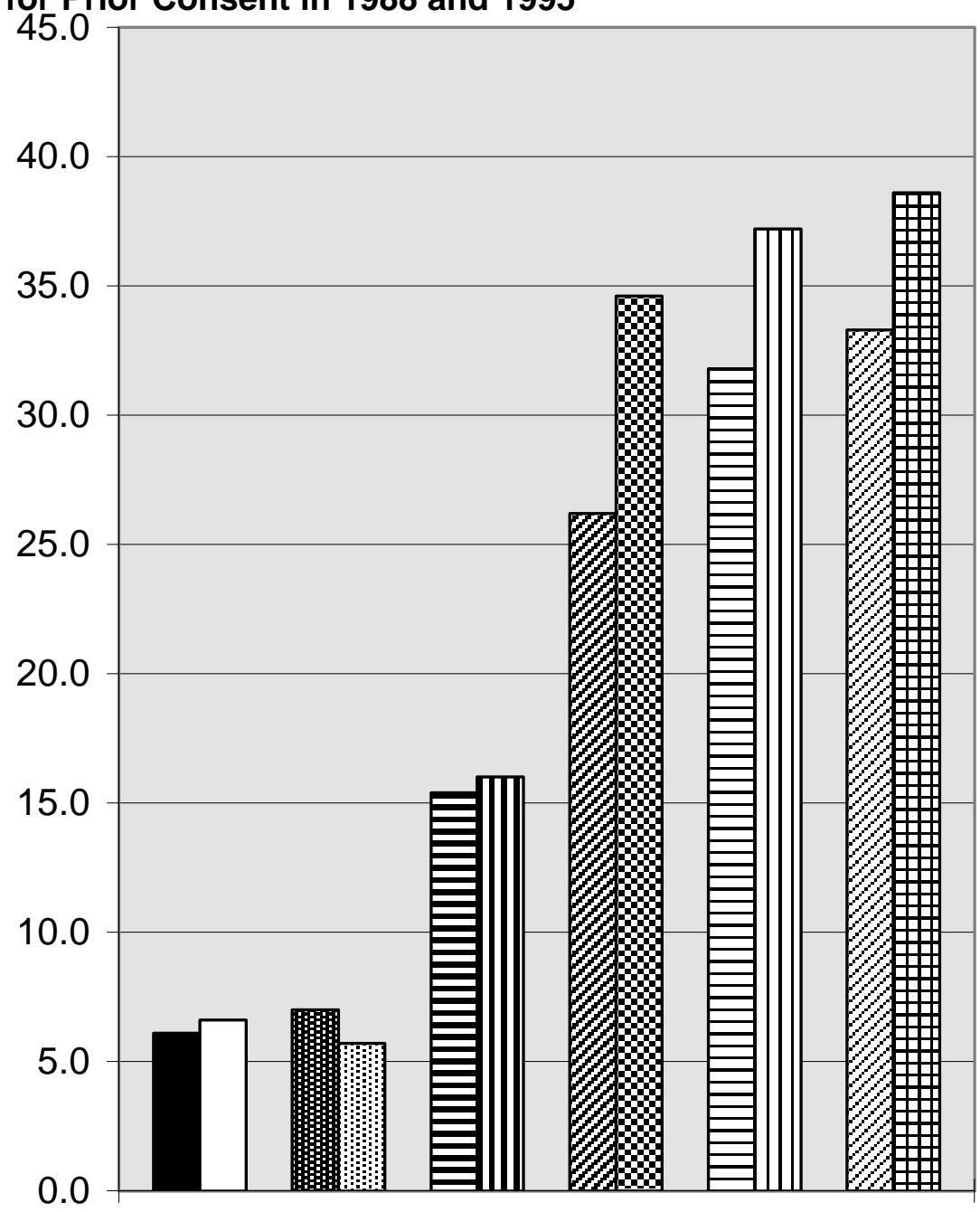

with union proportion of establishments with JLMCs discussing corporate restructuring that ask employee representatives for prior consent in 1988 (in percent)

$\square$ proportion of establishments with JLMCs discussing corporate restructuring that ask employee representatives for prior consent in 1995 (in percent)

圆

78 proportion of establishments with JLMCs discussing hiring and staffing that ask employee representatives for prior consent in 1988 (in percent)

耳proportion of establishments with JLMCs discussing hiring and staffing that ask employee representatives for prior consent in 1995 (in percent)

๑

Eproportion of establishments with JLMCs discussing transfer of employees that ask employee representatives for prior consent in 1988 (in percent)

D proportion of establishments with JLMCs discussing transfer of employees that ask employee representatives for prior consent in 1995 (in percent)

田

『proportion of establishments with JLMCs discussing layoff that ask employee representatives for prior consent in 1988 (in percent)

Qproportion of establishments with JLMCs discussing layoff that ask employee representatives for prior consent in 1995 (in percent)

\section{固}

Eproportion of establishments with JLMCs discussing mandatory retirement that ask employee representatives for prior consent in 1988 (in percent)

$\square$ proportion of establishments with JLMCs discussing mandatory retirement that ask employee representatives for prior consent in 1995 (in percent)

田

Q 0 proportion of establishments with JLMCs discussing severance pay/pension that ask employee representatives for prior consent in 1988 (in percent)

田proportion of establishments with JLMCs discussing severance pay/pension that ask employee representatives for prior consent in 1995 (in percent) 
FIGURE 11 Proportion of Non-unionized Establishments with JLMCs Discussing Restructuring and Other Relevant Issues that Ask Employee Representatives for Prior Consent in 1988 and 1995

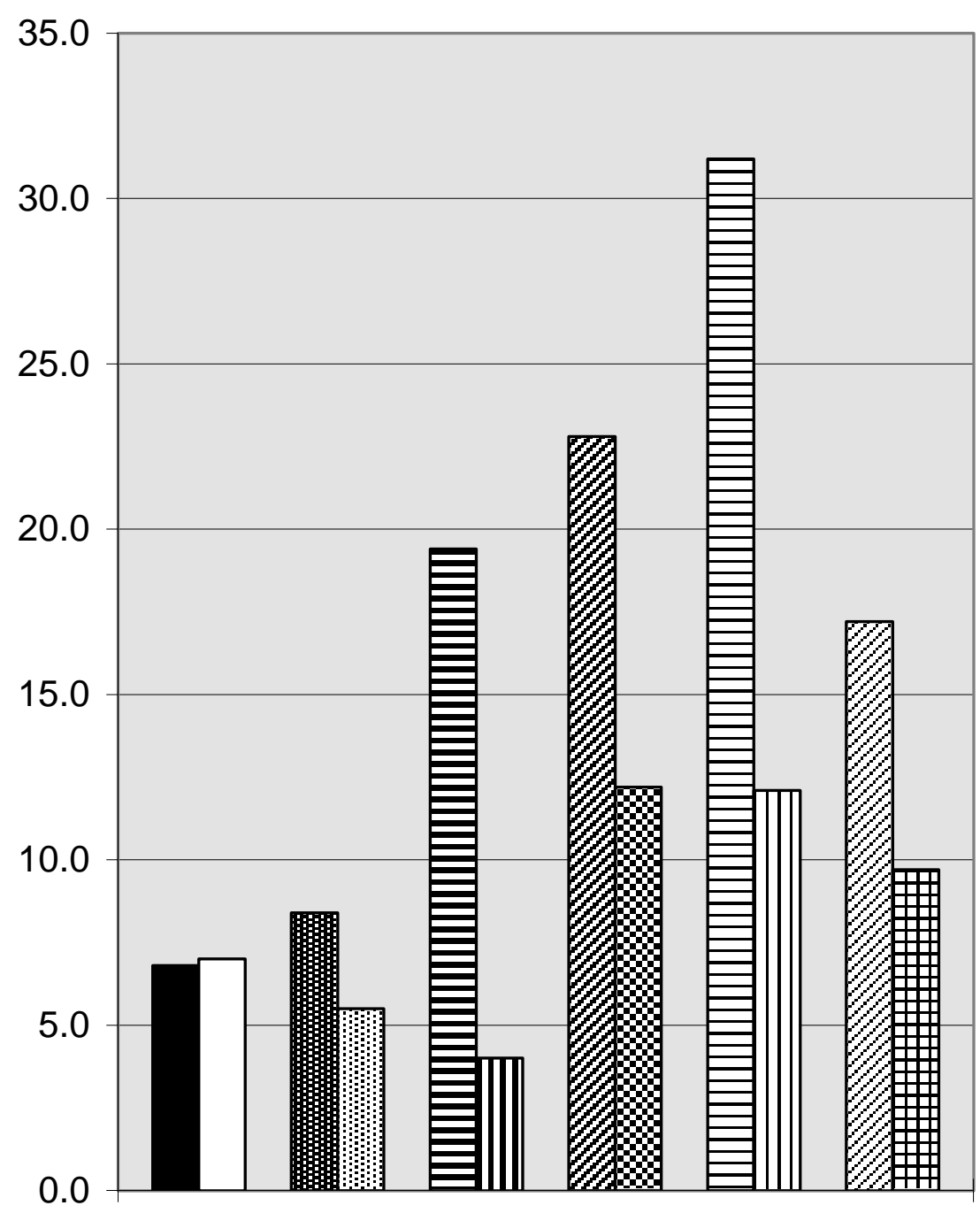

without union proportion of establishments with JLMCs discussing corporate restructuring that ask employee representatives for prior consent in 1988 (in percent)

口proportion of establishments with JLMCs discussing corporate restructuring that ask employee representatives for prior consent in 1995 (in percent)

图

Fproportion of establishments with JLMCs discussing hiring and staffing that ask employee representatives for prior consent in 1988 (in percent)

Fproportion of establishments with JLMCs discussing hiring and staffing that ask employee representatives for prior consent in 1995 (in percent)

-

Eproportion of establishments with JLMCs discussing transfer of employees that ask employee representatives for prior consent in 1988 (in percent)

Dproportion of establishments with JLMCs discussing transfer of employees that ask employee representatives for prior consent in 1995 (in percent)

$\mathbf{\square}$

Gproportion of establishments with JLMCs discussing layoff that ask employee representatives for prior consent in 1988 (in percent)

曰proportion of establishments with JLMCs discussing layoff that ask employee representatives for prior consent in 1995 (in percent)

$\mathbf{B}$

Dproportion of establishments with JLMCs discussing mandatory retirement that ask employee representatives for prior consent in 1988 (in percent)

$\mathbf{\square}$ proportion of establishments with JLMCs discussing mandatory retirement that ask employee representatives for prior consent in 1995 (in percent)

వ

चproportion of establishments with JLMCs discussing severance pay/pension that ask employee representatives for prior consent in 1988 (in percent)

$\square$ proportion of establishments with JLMCs discussing severance pay/pension that ask employee representatives for prior consent in 1995 (in percent) 
Figure 12 Changes in Key Firm Characteristics Over Time: Firm A

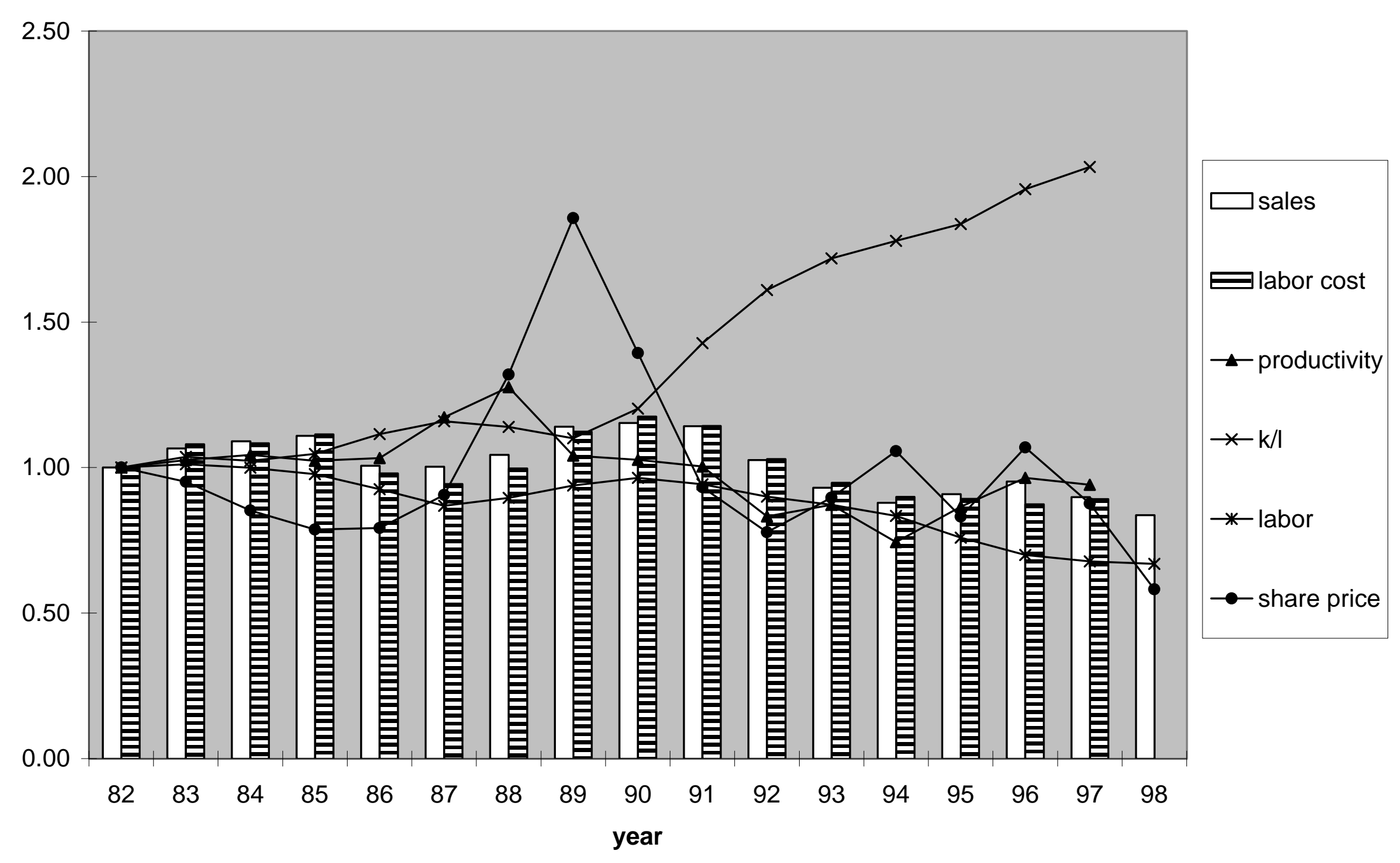


Figure 13 Changes in Firm Performance Measures Over Time: Firm A

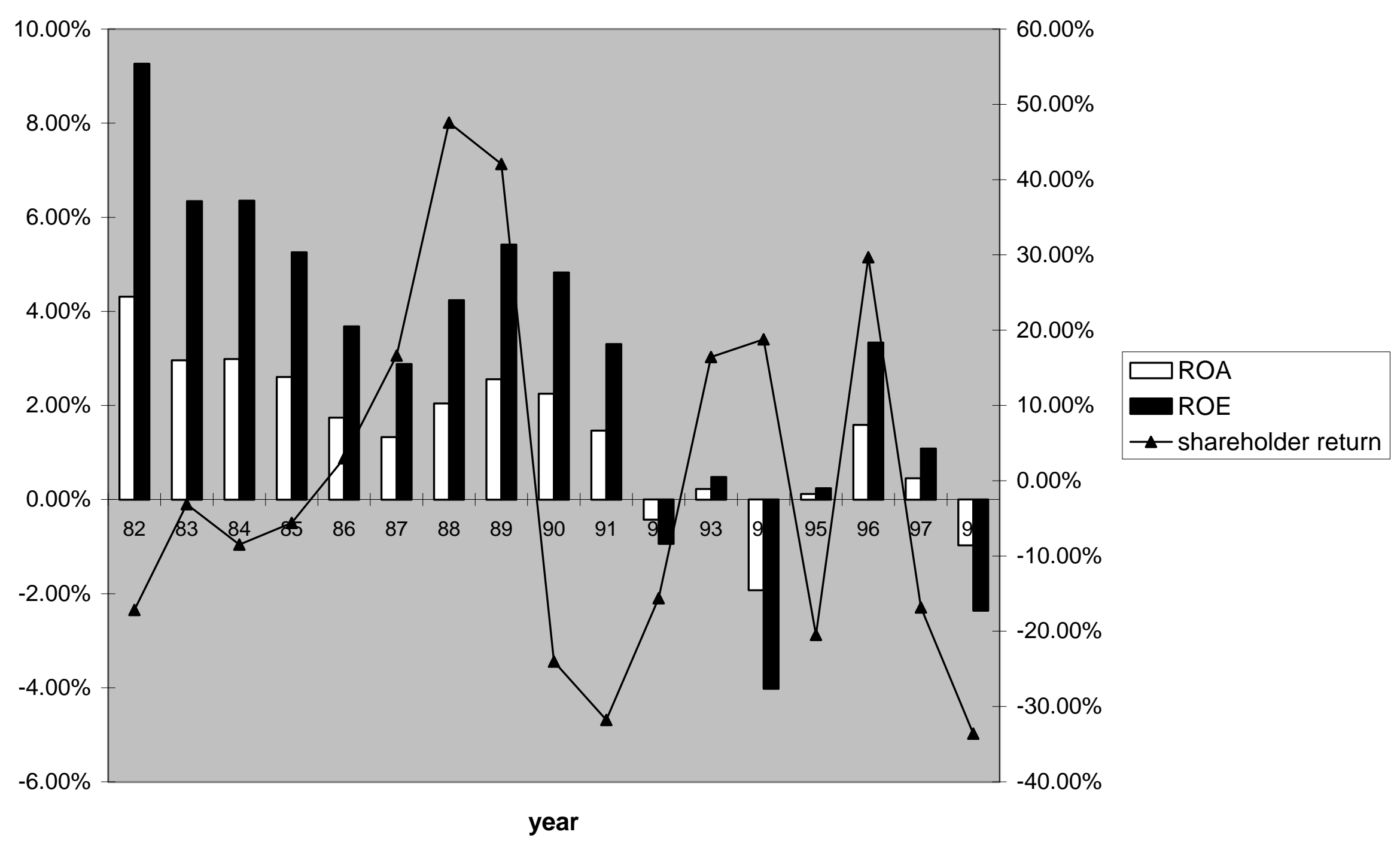


Figure 14 Changes in the frequency of HQ-JLMCs meetings over time: Firm A

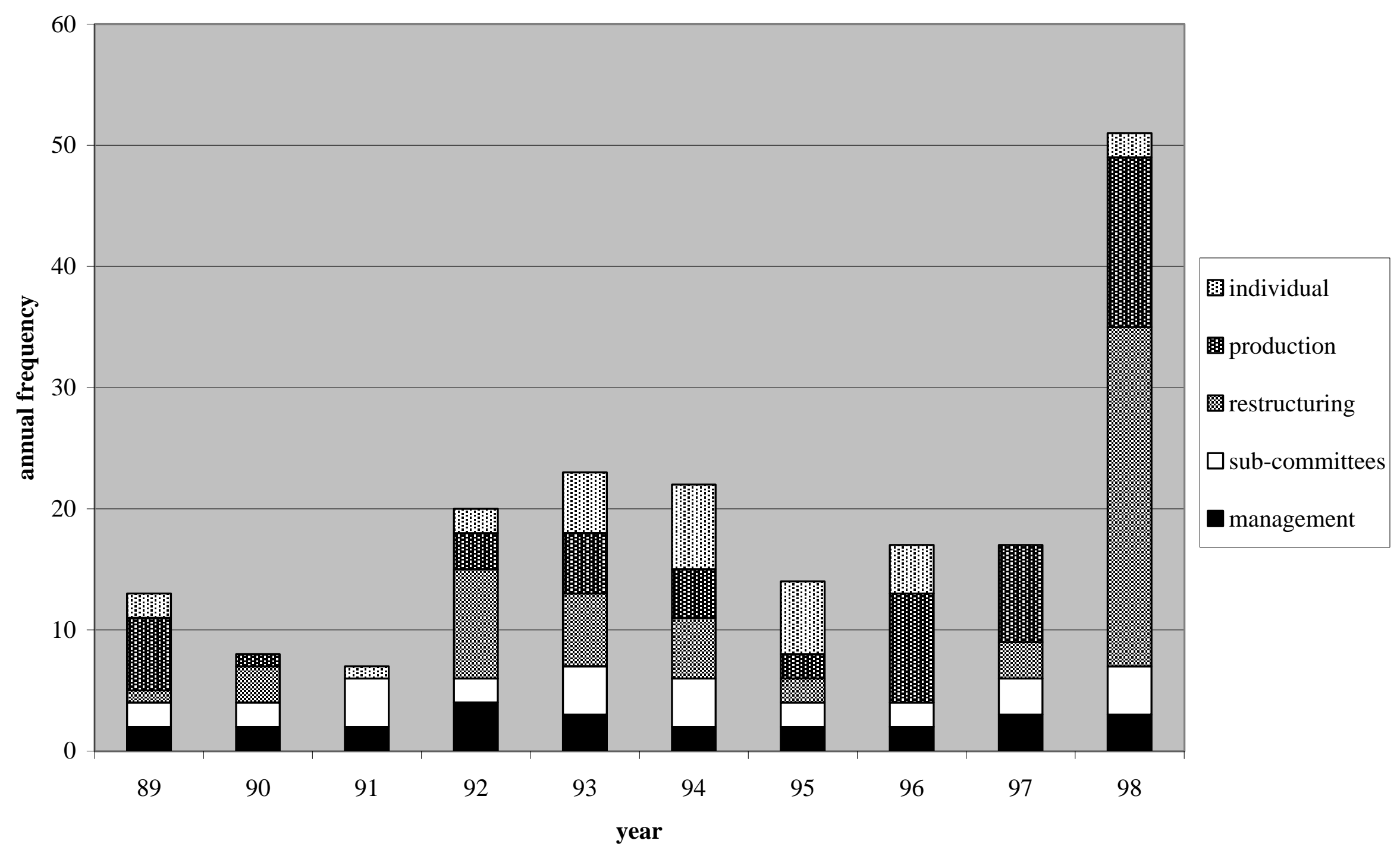


Figure 15 Changes in Key Firm Characteristics Over Time: Firm B

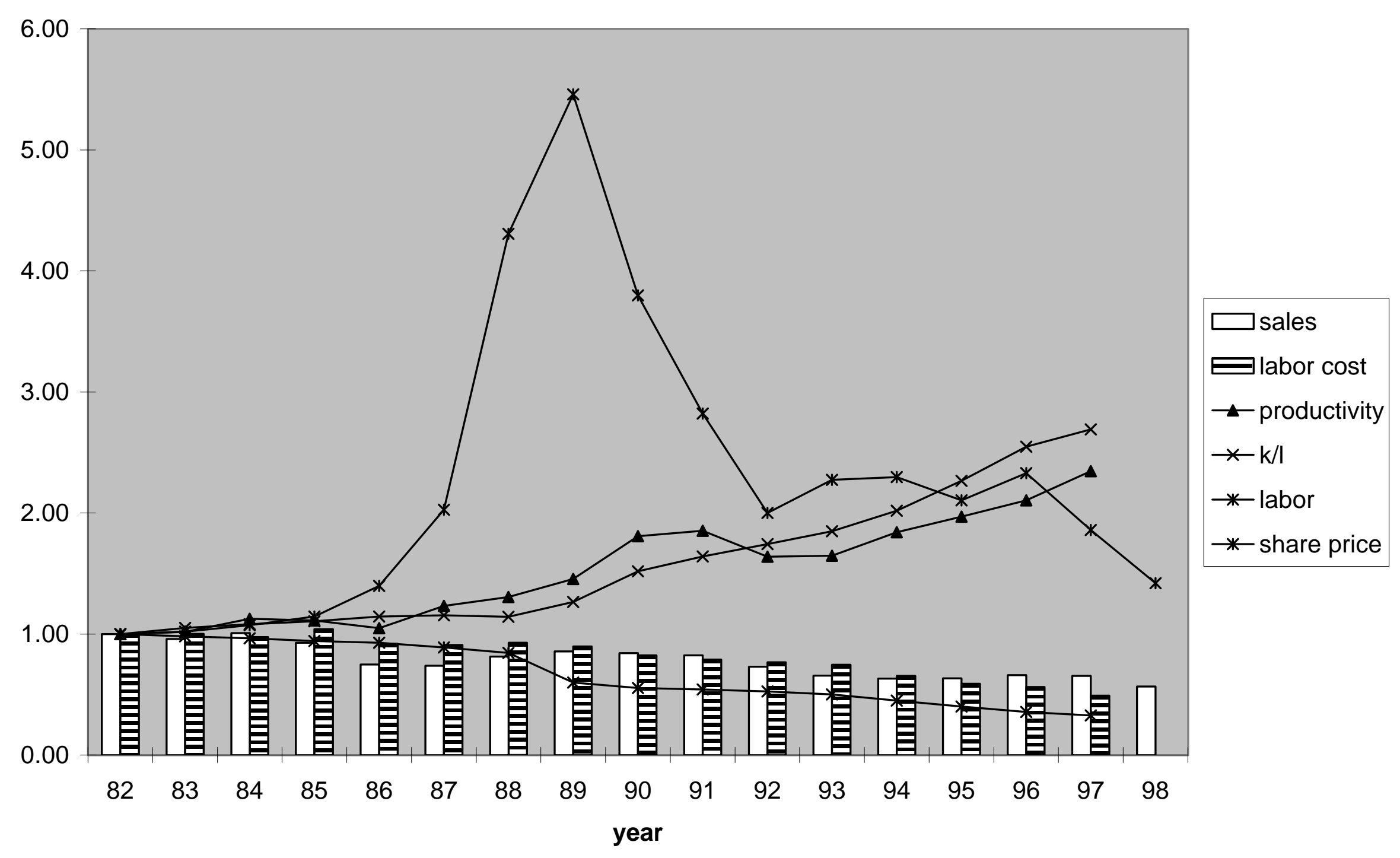


Figure 16 Changes in Firm Performance Measures Over Time: Firm B

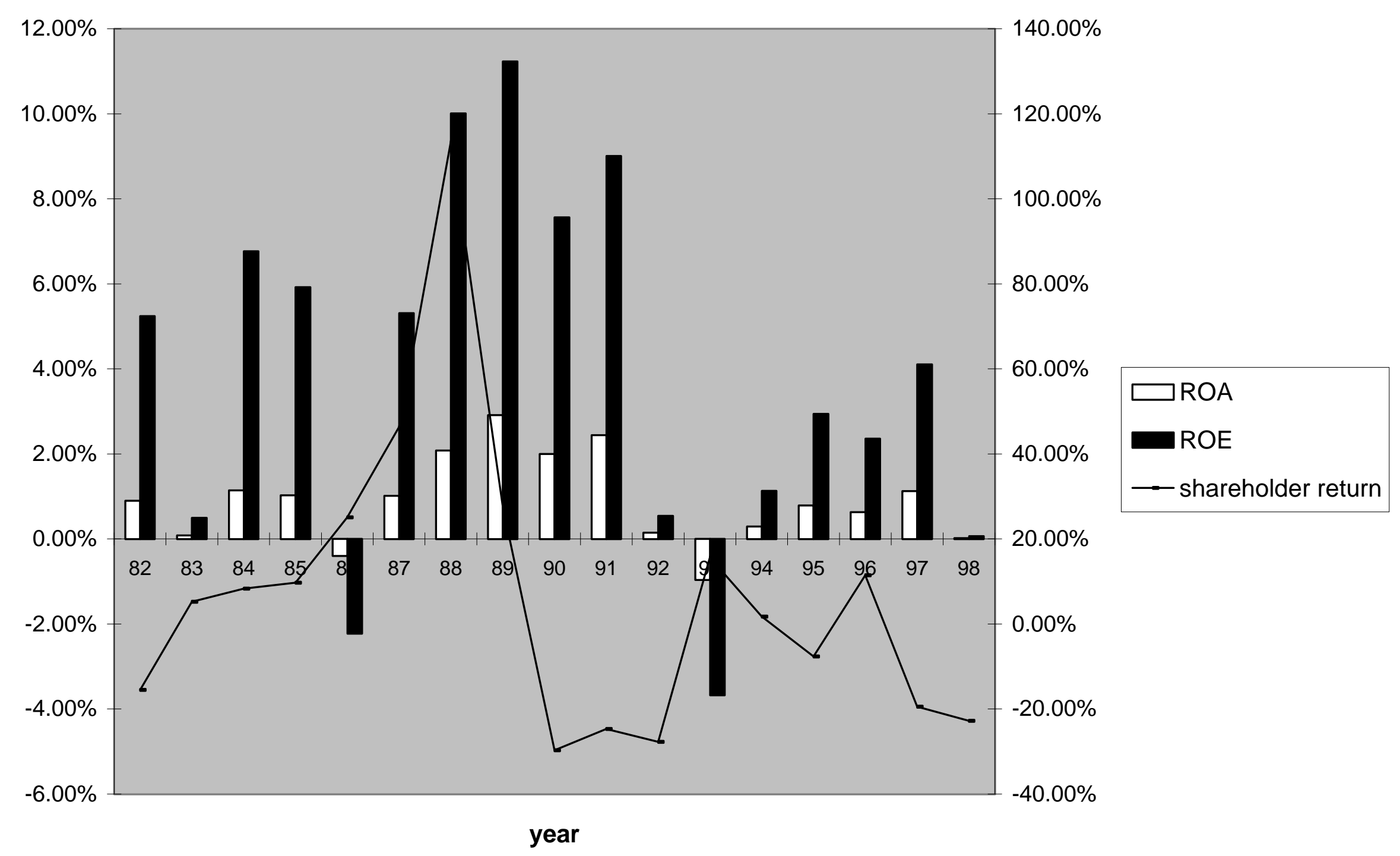


Figure 17 Changes in the frequency of JLMCs meetings and collective bargaining over time: Firm B

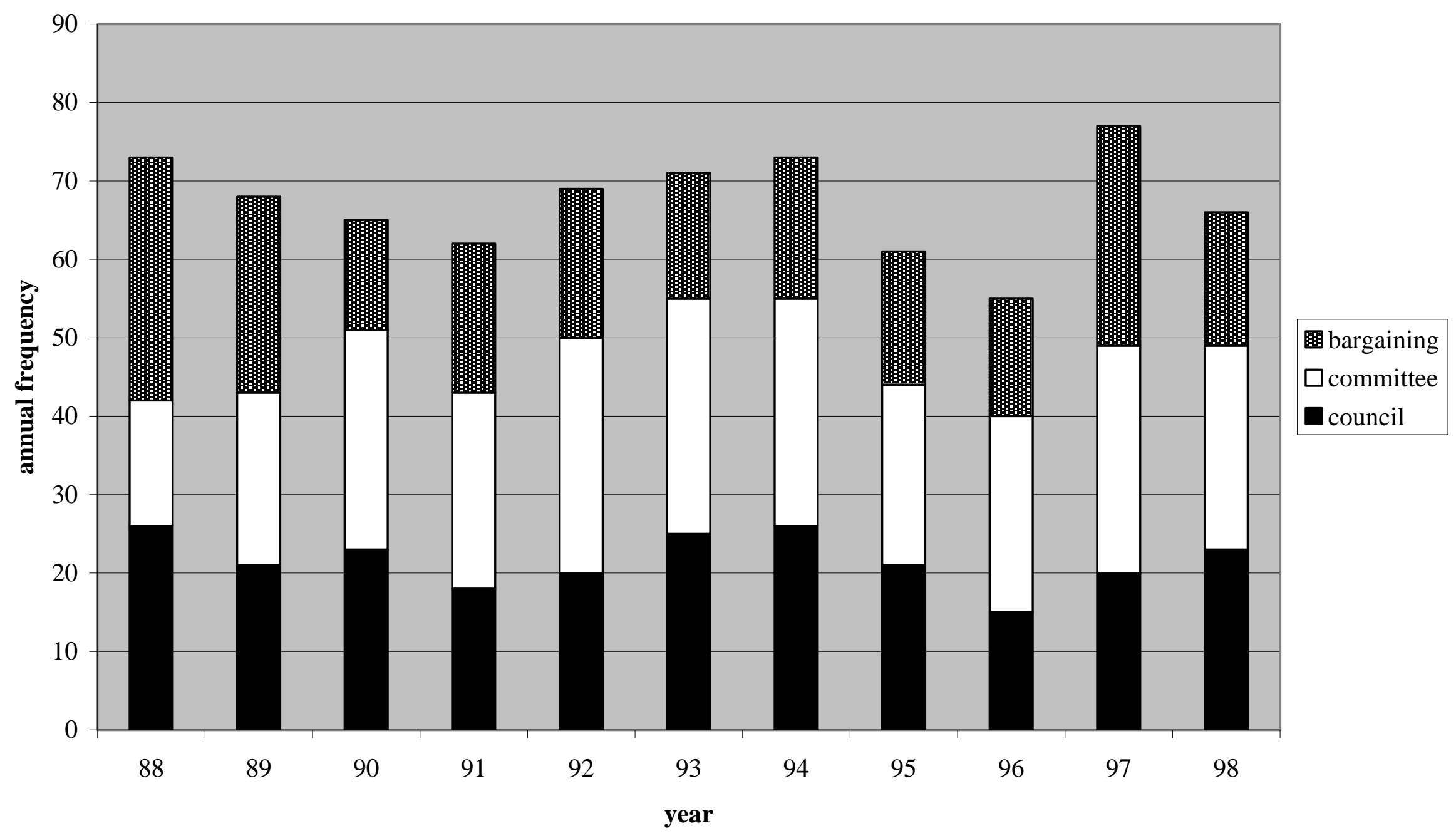


Figure 18 Changes in Key Firm Characteristics Over Time: Firm C

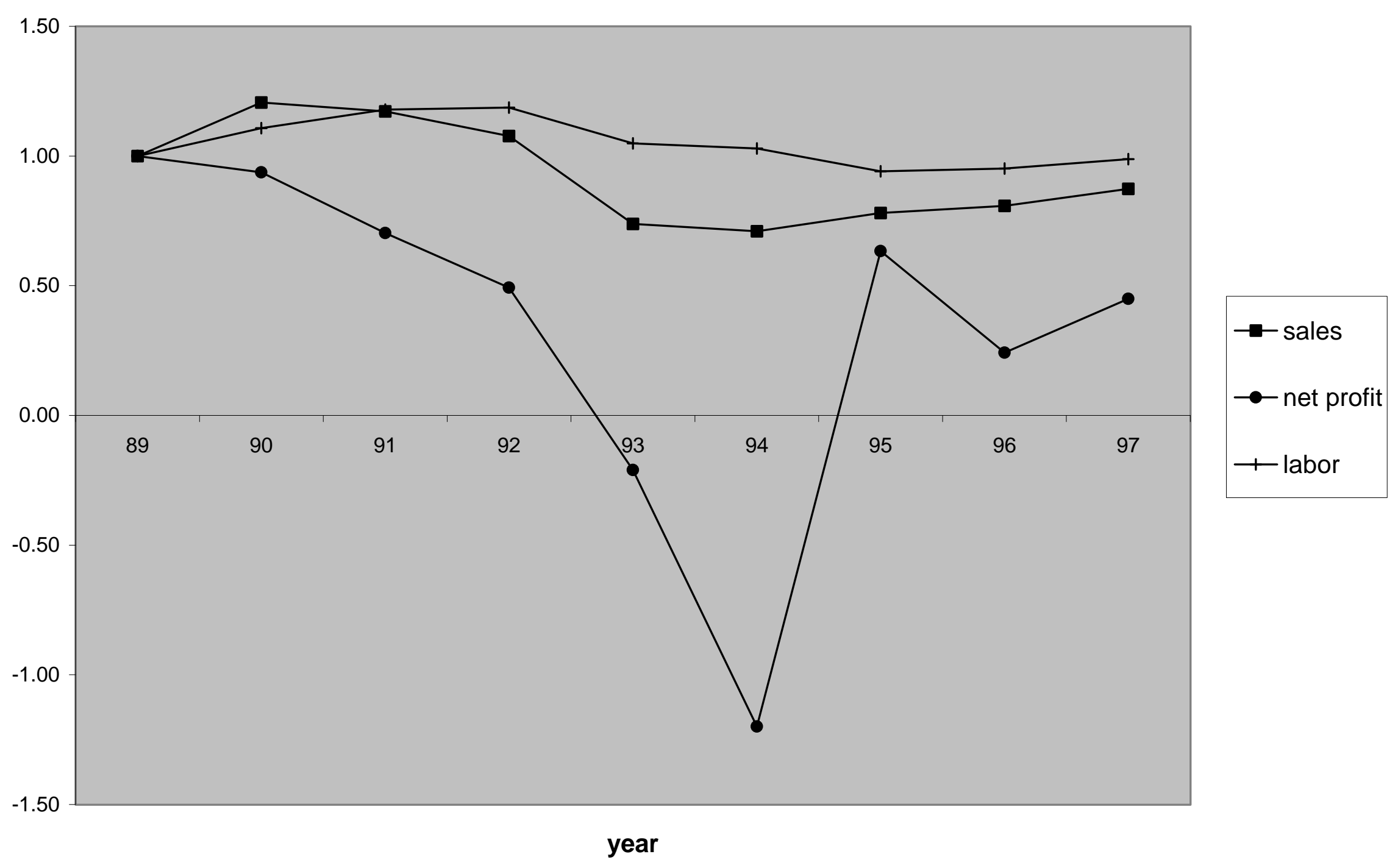


Figure 19 Changes in Firm Performance Measures Over Time: Firm C

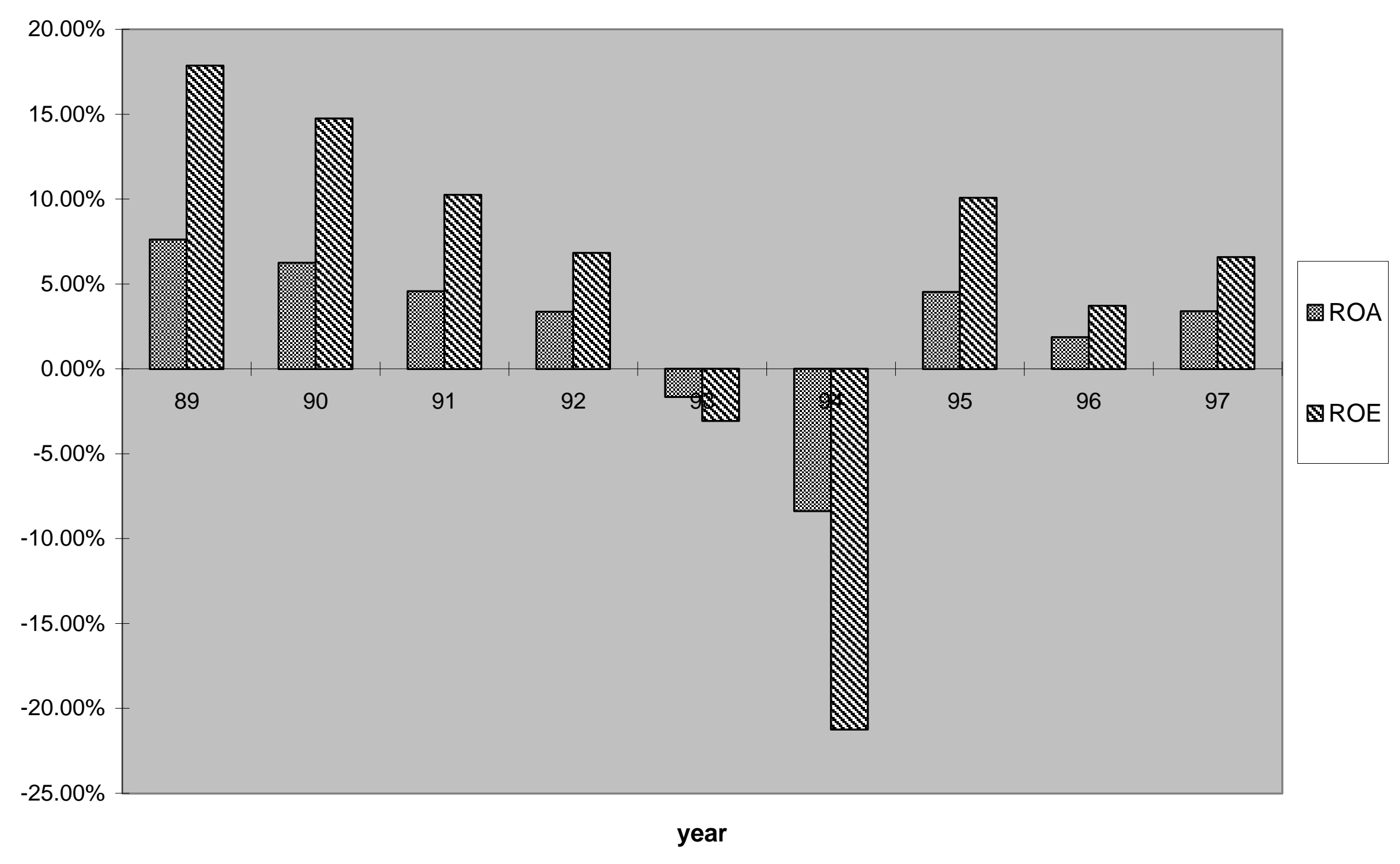


Figure 20 Changes in ESOP Participation and Contribution: Firm D

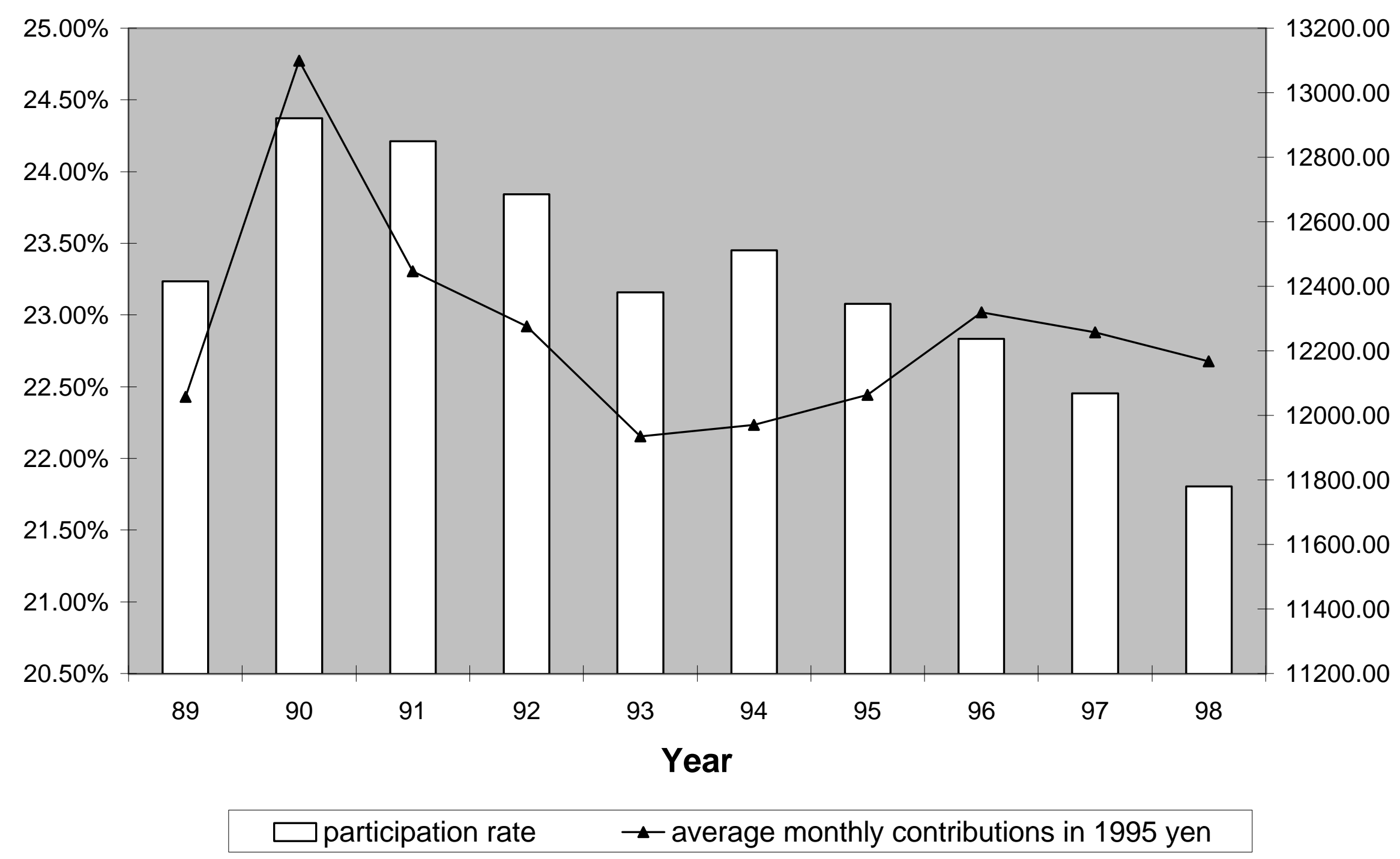


Figure 21 Changes in New ESOP Participants: Firm D

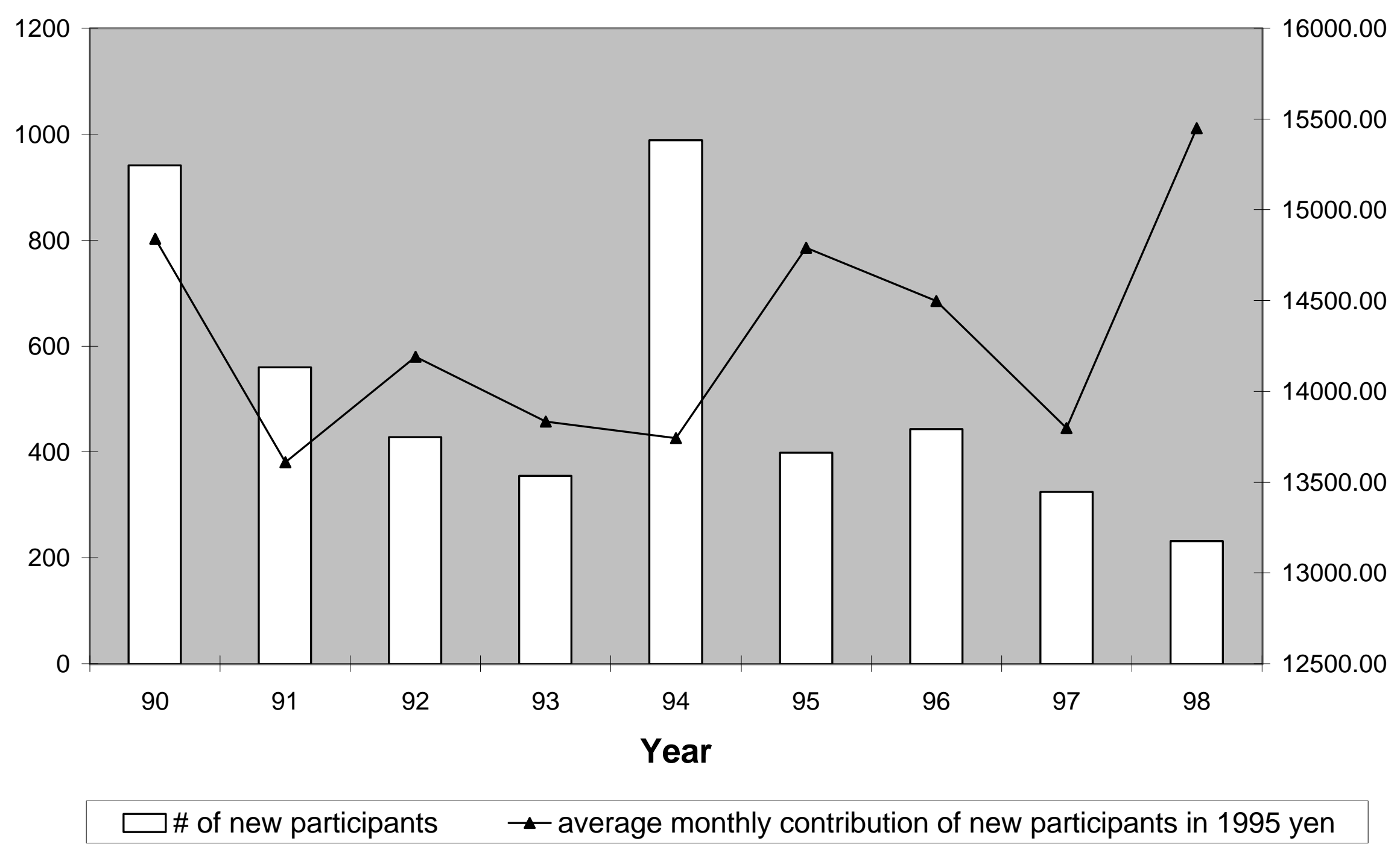




\section{Figure 22 Changes in Exiting ESOP Participants: Firm D}

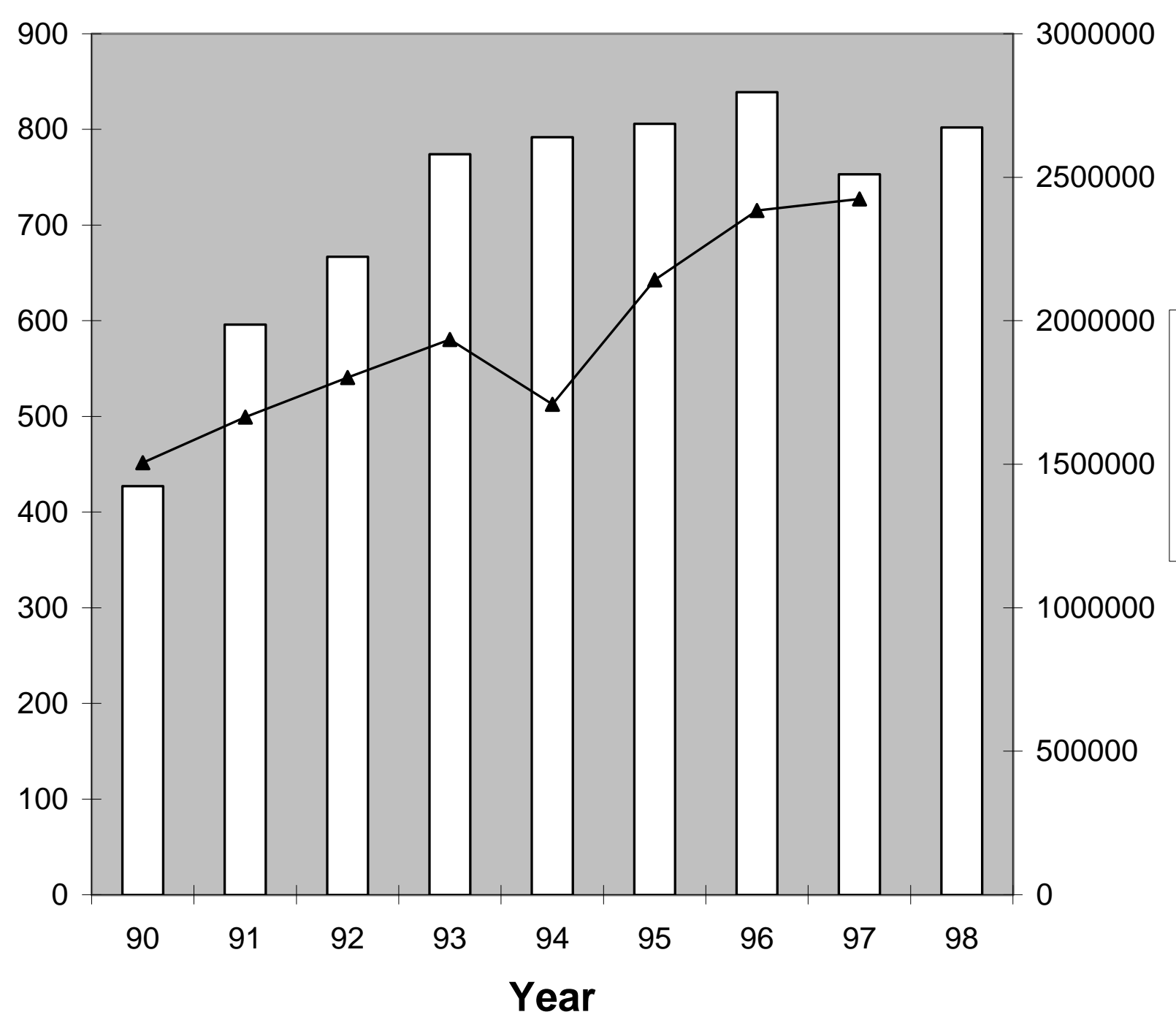

$\square$ \# of exiting participants

$\rightarrow$ average accumulation of exiting participants in 1995 yen 


\section{Figure 23 Direct Cost of ESOPs: Firm D}

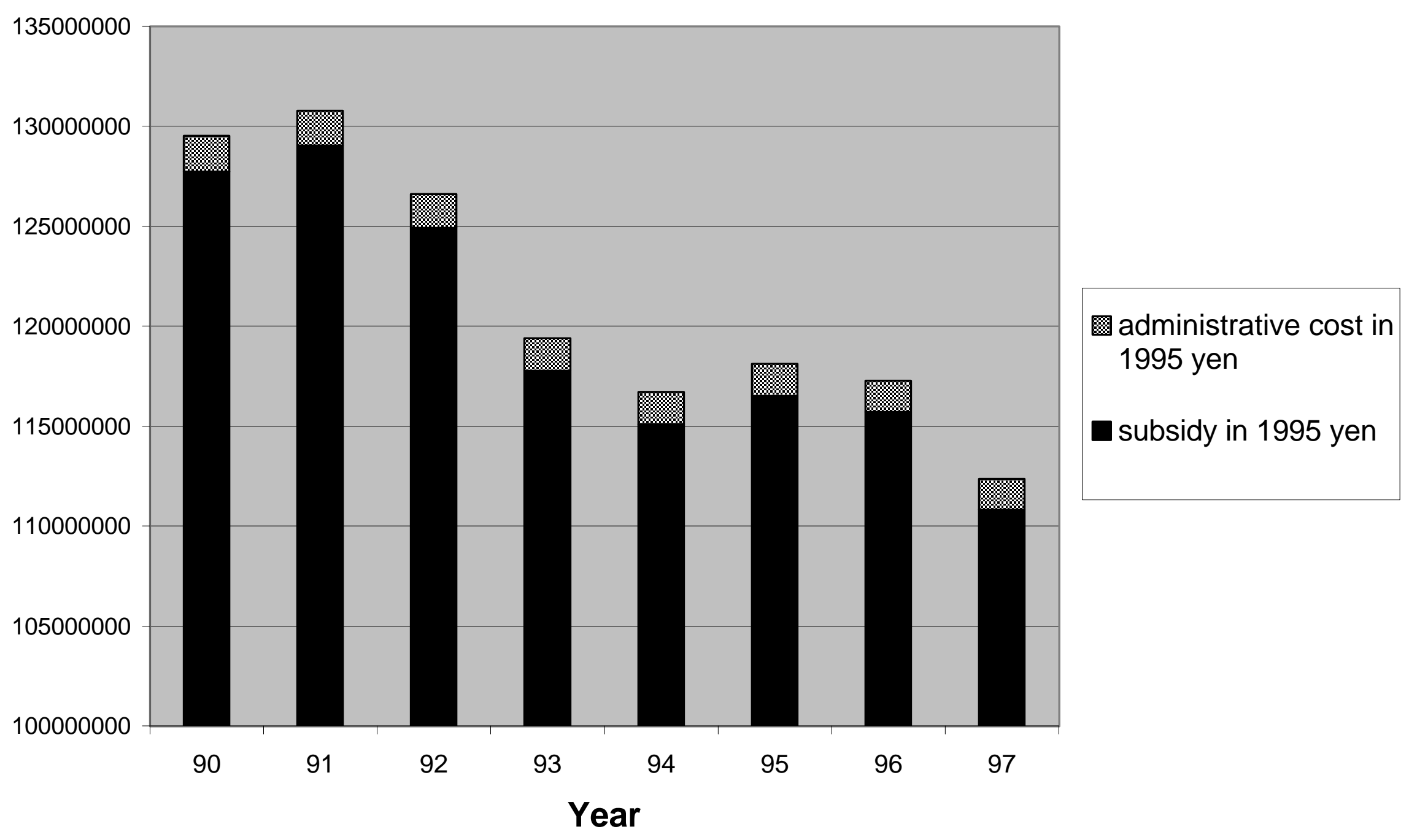


Figure 24 ESOP Participants Who Reduced and Increased Contributions: Firm D

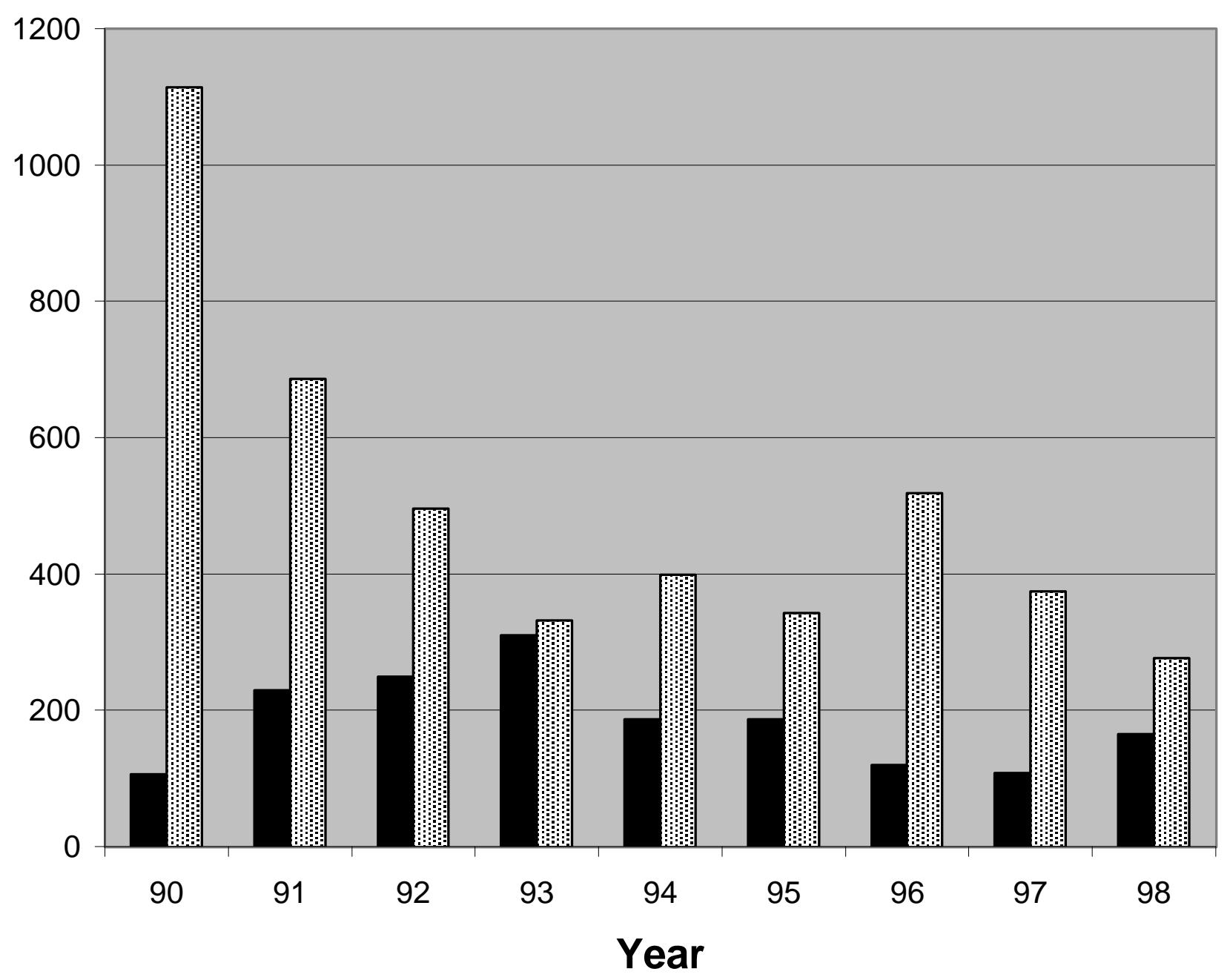

\# of participants who reduced their monthly contributions

圈\# of participants who increased their monthly contributions 